\title{
Stanowisko króla w Rzeczypospolitej na podstawie listów ostatniego Jagiellona do Radziwillów
}

\author{
Der König Polens im Licht der Briefe des letzten \\ Jagiellonen an die Familie Radziwill
}

1. Pojawienie się listów w języku poiskim. 2. Listy jako źródło badań historycznych: 2.1. Charakter źródła; 2.2. Wady tego typu źródeł; 2.3. Edycja I. Kaniewskiej; 2.4. Listy jako żródło wiadomości o Zygmuncie II Auguście. 3. Znaczenie informacji w rządzeniu państwem: 3.1. Tematyka publiczna a prywatna w listach - 3.1.1. Egzekucja praw i dóbr w listach, 3.1.2. Unia polsko-litewska, 3.1.3. Religia, reformacja, 3.1.4. Następstwo tronu, 3.2. Stosunek Zygmunta Augusta do opozycji; 3.3. Sprawy zarządu państwem w listach - 3.3.1. Nominacje, 3.3.2. Spory między urzędnikami, 3.3.3. Sprawy skarbowe, 3.3.4. Wymiar sprawiedliwości, 3.3.5. Sprawy opieki, 3.3.6. Protekcje, 3.3.7. Łaska królewska; 3.4. Sprawa Barbary; 3.5. Konflikt króla z matką; 3.6. Sprawy zagraniczne. 4. Podsumowanie.

1. Briefe in polnischer Sprache. 2. Briefe als historische Quelle: 2.1. Charakter der Quelle; 2.2. Fehler im derartigen Quellmaterial; 2.3. Ausgabe von I. Kaniewska; 2.4. Briefe als Informationsquelle über Sigismund II. August. 3. Bedeutung der Information für die Staatsführung: 3.1. Öfrentliche und private Themen - 3.1.1. Rechts- und Gütervollstreckung in den Briefen, 3.1.2. Polnisch-Litauische Union, 3.1.3. Religion, Reformation, 3.1.4. Thronfolge; 3.2. Sigismund II. August und die Opposition; 3.3. Staatverwaltung in Briefen - 3.3.1. Ernennungen, 3.3.2. Streitigkeiten zwischen den königlichen Beamten, 3.3.3. Fiskusangelegenheiten, 3.3.4. Justiz, 3.3.5. Fürsorgeangelegenheiten, 3.3.6. Forderung, 3.3.7. Ko nigliche Gnade; 3.4. Barbara Gasztołdowa in Briefen; 3.5. Streit zwischen dem König und seiner Mutter; 3.6. Auswärtige Angelegenheiten. 4. Resümee.

1. Listy pisane $w$ języku polskim pojawily się $w \mathrm{XV}$ w. ${ }^{1} \mathrm{~W}$ pierwszej polowie XVI w. liczba piszących w języku polskim powiększa się, poszerza się też zakres spraw, których one dotyczą. Nadawcami listów byli senatorowie, szlachta, mieszczanie i monarchowie.

Listy polskie XVI wieku, red. K. Rymut, t. I: lisiy z lat 1525-1548 ze zbiorów Wl. Pociechy, W. Taszyckiego i A. Turasiewicza, Kraków 1998, s. V. 
Okres panowania Zygmunta II Augusta cieszy się żywym zainteresowaniem historyków. Do badań nad rządami tego wladcy wykorzystuje się liczną już epistolografię. W okresie Odrodzenia na terenie Królestwa Polskiego wyróżniają się tacy korespondenci, jak np. Jan Dantyszek, Stanisław Hozjusz, Marcin Zebrzydowski, Marcin Kromer, Jan Zamoyski. Ważne miejsce wśród nich zajmuje ostatni $\mathrm{z}$ dynastii Jagiellonów na tronie królewskim - Zygmunt II August. Zachowała się jego korespondencja z Radziwiłłami. Dysponujemy różnymi wydaniami listów ${ }^{2}$, ostatnio ukazał się zbiór listów tego władcy pisanych do Radziwiłłów ${ }^{2 a}$.

W zbiorze wydanym przez Irenę Kaniewską zamieszczonych zostało 365 listów, których adresatami byli Radziwiłłowie: głównie Mikolaj zwany Rudym (213 listów), Mikołaj zwany Czarnym (136 listów). Nieliczne listy wysłane były do jego żony Barbary Gasztołdowej (3 listy), do jej matki Barbary z Kolów Radziwiłłowej (5 listów), Mikołaja Krzysztofa zwanego Sierotką (8 listów), Krzysztofa Radziwiłła zwanego Piorunem (1 list). W zbiorze zamieszczonych zostało 338 listów napisanych po polsku, $20-w$ języku ruskim $\mathrm{i}$ siedem po łacinie $^{2 \mathrm{~b}}$.

2. List jest szczególnym źródlem historycznym $\mathrm{w}$ badaniach nad ustrojem państwa. To materiał barwny, stylistycznie różnorodny, sprawiający jednak czasem trudności interpretacyjne. Jest on zarazem źródłem bardzo nietrwałym, narażonym na zniszczenie. Często nadawca nakazywał wręcz zniszczenie listu po jego przeczytaniu. I wówczas byt jego uzależniony był od lenistwa adresata, który nie zawsze stosował się do polecenia nadawcy ${ }^{3}$. Zalety tego

\footnotetext{
${ }^{2}$ Przyciągaly one uwage już w XIX w. Pierwszym ich edytorem był Julian Ursyn Niemcewicz, który opublikował niewielki ich zbiór w 1822 r. Kolejnymi w XIX w. byli: Stanisław A. Lachowicz, Michał Baliński, Aleksander Przeździecki. W dwudziestoleciu międzywojennym wymienić możemy Józefa Jasnowskiego, zaś po 1945 r. Witolda Taszyckiego.
}

${ }^{2 a}$ Listy króla Zygmunta Augusta do Radziwillów, oprac., wstęp, komentarz I. Kaniewska, Kraków 1997. Listy króla... spotkały się z dużym zainteresowaniem, zob. artykuł recenzyjny: M. J a n i cki, R. J a w or ski, Nad nowq edycjq listów króla Zygmunta Augusta. „Listy króla Zygmunta Augusta do Radziwillów, opracowanie, wstẹp i komentarz I. Kaniewska, Wydawnictwo Literackie, Kraków 1999, s. 647+1. il. 4", Przegląd Historyczny 1999, t. XC, z. 3, s. 347-364.

${ }^{2 b}$ Podstawą do napisania artykułu są: Listy króla Zygmunta Augusta... wydane drukiem przez 1. Kaniewską. Zbiór ten nie zawiera wszystkich listów ostatniego Jagiellona, które dotrwały do naszych czasów, zob. M. J a nicki, R. J a worski, Nad nowq..., s. 361-364. Autorzy dołączyli aneks, w którym zamieścili zestawienie, będące wynikiem wyrywkowej kwerendy listów, które nie zostały dotąd wydane drukiem; zob. również R. Jaw orski, Nieznana korespondencja króla Zygmunta Augusta z Mikolajem Radziwillem $i$ Ostafim Wollowiczem z lat 1550-1571 ze zbiorów Biblioteki Czartoryskich (art. w druku w: Studia Źródloznawcze 2002). Pragnę w tym miejscu podziękować Autorowi mgr R. Jaworskiemu za udostępnienie tekstu powyższego artykułu

${ }^{3}$ Listy króla.., nr 15 z 25 VII 1548 r. do Mikołaja Rudego, s. 64; zob. też: U. A u gu st y niak, Informacja $i$ propaganda $w$ Polsce za Zygmunta III, Warszawa 1981, s. 134-135, 142; 
rodzaju źródel dla badań historyczno-prawnych są duże. Pozycja monarchy w panstwie byla wyjątkowa - nadrzędna w stosunku do osób, do których pisał. Listy były jednym $\mathrm{z}$ instrumentów zarządzania państwem. Tematyka listów pozwala nam zapoznać się ze stanowiskiem głowy państwa w różnych sprawach - tak państwowych, jak i niepaństwowych. Dają nam one możliwość oceny nadawcy tych listów jako polityka, pozwalając zobaczyć instytucje monarchy jego oczyma, skoro kształt tej instytucji zależał w dużej mierze od osobowości jednostki sprawującej urząd królewski.

2.1. Monarchę znamy $\mathrm{z}$ oficjalnych wypowiedzi, które siłą rzeczy podlegały pewnej cenzurze. W listach do osób zaufanych mógl władca pozwolić sobie na większą otwartość i szczerość. Wynika to ze sformułowań zamieszczonych w listach do jego adresatów, w których piszący wyraża pełne zaufanie, jakie żywil dla odbiorcy. Zygmunt II August pisal w listach do Mikolaja Rudego Radziwiłła, iż zawżdy o wszytkim $z$ wami zwykli confidenter traktować $i$ do was o wszystko libere pisywać... ${ }^{4}$. Król nie jest skrępowany, mając zaufanie do adresatów; kładzie jednak nacisk na to, aby adresat zachował pełną

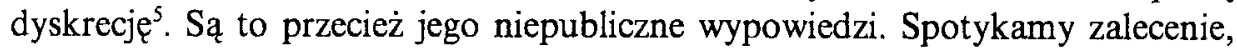
aby adresat, udzielając listownej odpowiedzi, przy pisaniu nie posługiwał

A. B. Zakrzewski, Sejmik Wielkiego Księstwa Litewskiego XVI-XVIII w. Ustrój i funkcjonowanie: sejmik trocki, Warszawa 2000, s. 18; R. J a w or s k i, Nieznana korespondencja..., s. 1, przyp. $2 \mathrm{z}$ odesłaniem do: Testament Zygmunta Augusta, oprac. A. Franaszek, O. Laszczyńska i S. E. Nahlik, Kraków 1975, s. 40-41 [Źródła do dziejów Wawelu, t. VIII].

+ Listy króla..., dopisek, $\mathrm{nr} 86$ z 3 V 1550 r., s. 173. W liście z 29 IX 1553 r. do Mikołaja Rudego król pisał: $O$ czym wszytkim z TM jako z radq naszym, któremu ufamy si non dabitur coram, tedy jenak przez listy libere et confidenter komunikować bęziemy, abowiem sie to tycze obrażenia zwierzchności naszej $i$ tez obrażenia pokoju pospolitego. Lecz o tym wszytkim aut coram aut per litteras latius, bo jeśli w innych rzeczach wszytkich zawżdy dufajqc we wszytkim osobliwie TM tedy pogotowiu teraz gdzie wżdy idzie o obrażenie zwierzchności naszej TM rady jako tego któregośmy uprzejmej życzności doznali, potrzebować bẹdziemy..., nr 155, s. 285. Zob. też nr 75 z 17 IIl 1550 r., s. 155; nr 78 z 28 III 1550 r., s. 162; nr 86 z 3 III 1550 r. do Mikołaja Rudego, s. 173; nr 122 z 20 V 1552 r. do Mikołaja Rudego, s. 236; nr 129 z 7 I 1553 r. do Mikołaja Rudego, s. 246; nr 153 z 7 IX 1553 r. do Mikołaja Czarnego, s. 281; nr 190 z 20 XII 1556 r. do Mikołaja Czarnego, s. 329; nr 239 z 16 XI 1562 r. do Mikołaja Czarnego, s. 401 ; nr 287 z 17 I 1565 r. do Mikołaja Czarnego i Mikołaja Rudego, s. 500.

' Jakoż wam [Mikołaj Rudy] i pan marszalek brat wasz [Mikołaj Czarny] szerzej okoto tego wszytkiego pisać ma i to wszytko dostatecznie z listu jego wyrozumieć będziecie mogli, jeno was o to i po wtóre żaqdamy i pilnie napominamy, żebyście sie tego, co do was na tej cedule piszemy, żadnemu czlowiekowi, by też napowinowatszy bel nie zwierzali, abowiem nam w tej mierze na tym, aby to jako natajemniej belo, barzo wiele a snać wszytko zależy. Jakoż w tym nic nie watpiemy, iż to tak tajemnie u siebie bedziecie mieli, patrzajqc $w$ tym na nasze i na królowej Jej M malzonki naszej potrzeby..., ibidem, nr 90 z VI $1550 \mathrm{r}$. do Mikołaja Rudego, s. 179; zob. również: nr 58 z 4 VIII 1549 r. do Mikołaja Rudego, s. 127; nr 177 z 30 I 1555 r. do Mikołaja Czarnego, s. 304. 
się osobą trzecią ${ }^{6}$. Wyjątkowo król akceptował sytuację, iż listy do niego nie były pisane własnoręcznie przez Mikołaja Rudego, co spowodowane było stanem zdrowia nadawcy. Król zalecał, aby w tym wypadku pisarzem był człowiek zaufany, który by pisowal od $W M$ do nas in secretis zwlaszcza W jednym $z$ listów natrafiamy na wiadomość, iž dworzanin służący Barbarze przekazywał listownie osobie trzeciej informacje o wszystkim, co się wokól Barbary działo. Nie wiemy, w jaki sposób Zygmunt August wszedł w posiadanie tego listu ${ }^{8}$. Monarcha przesłał przechwycony list Mikołajowi Rudemu, nakazując, aby nie ujawniając wiedzy o liście, porozmawiał z jego autorem, by ten nie ważył się tego dalej czynić. $\mathrm{W}$ jednym $\mathrm{z}$ dopisków dołączonych do korespondencji natrafiamy na polecenie, by adresat nie rozstawał się $z$ listem, względnie go zniszczylin. Taka postawa autora listów nie pozbawia tego źródla wartości poznawczych, które są w nich zawarte. Dają one możliwość czytelnikowi poznania osoby ostatniego Jagiellona jako polityka. Treść korespondencji ukazuje jego stanowisko wobec problemów absorbujących jego uwagę.

2.2. Wadą tego źródła jest to, że nie wszystko, co miał do powiedzenia nadawca, zamieszczał $w$ tekście. Monarcha mial świadomość, iż sprawy o których pisze w listach, mogą przeniknąć na zewnątrz, dlatego wspomina o nich czasem oględnie, nie ujawniając racji, które go skłoniły do podjęcia określonych decyzji ${ }^{11}$. Napotykamy w nich na ustępy, w których nadawca

\footnotetext{
'A iż sie omawiacie, że ten list od Jej KM rẹkq wasza do nas za panem wojnickiem jest pisan, tedy $i$ tego nie ganimy $i$ owszem radzi widziec będziemy, iz gdy sie tak co trafi tajemnego, abyście więc sami podczas rẹkq swa od królowej Jej $M$ do nas pisali..., ibidem, nr 38 z 20 XII $1548 \mathrm{r}$. do Mikołaja Rudego, s. 100. W liście do Mikołaja Rudego z 9 VIII $1568 \mathrm{r}$. pisał, iz z Warszawy potrzeba się téz bedzie nam z TM pilno porozumieć, przeto co sie tam spravi na on czas listem naszym nic nie mieszkajac oznajmić TM rozkażemy. A bedzieli co barzo pilnego et sekretnego, tedy tegoż pisarza naszego rzucimy $k u T M, g d y \dot{z} w$ najmniejszej sprawie nie chcielibyśmy nic dzialać bez madre[go] zdania TM..., nr 321, s. 543-544. Nasuwa się pytanie czy monarcha miał na myśli brak zaufania do pisarza, którym posługiwał się adresal, czy też wymieniony pisarz królewski miałby ustnie dostarczyć ważne wiadomości? Ibidem, nr 358 z 5 IX 1571 r., s. 603.

${ }^{8}$ U. Augustyniak stwierdza, iż $w$ okresie panowania Zygmunta III stało się praktyką przejmowanie i czytanie listów prywatnych, które dwór uznał za podejrzane, tejże, Informacja i propaganda..., s. 143.

'Listy króla.., nr 11 z 2 VI 1548 r., s. 54.

${ }^{10}$ Ale to przy sobie miejcie, $i$ owszem te kartke zdrapcie albo spalcie..., ibidem, $\mathrm{nr} 15$ z 25 VII 1548 r. do Mikolaja Rudego, s. 64.

${ }^{11} \mathrm{~W}$ liście z 24 X $1548 \mathrm{r}$. do Mikołaja Rudego, sprzeciwiając sie jego spotkaniu z wojewodą krakowskim Piotrem Kmitą, pisał: Abowiem tego sq wlasne przyczyny, których sie natenczas listom wierzyć nie godzi, przecz tego jest potrzeba, iebyście sie teraz z wojewodq nigdzie nie zjeżdzali..., ibidem, nr 24, s. 77; zob. nr 57 z 3 VIII 1549 r. do Mikolaja Czarnego, s. 125, mimo zastrzeżenia, że nie wszystko można bezpiecznie powierzyć listom, król stwierdzał: ...my hoc quod sentimus, scribimus; nr 70 z 31 I 1550 r. do Mikołaja Rudego, s. 145; nr 72 z 16 II 1550 r. do Mikołaja Rudego, s. 150.
} 
informuje adresata o tym, że osoba dostarczająca list przekaże mu informacje ustnie, którym ma dać wiarę ${ }^{12}$. Czasem natrafiamy na wzmianki świadczące, że również adresat, odpowiadając na list monarchy, udzielal przez swojego dworzanina ustnej odpowiedzi ${ }^{13}$. W związku z planowanym przyjazdem króla na Litwę lub adresata do Korony, Zygmunt II August odkładał szczegółowe omówienie interesującej go sprawy do osobistego z nim spotkania ${ }^{14}$. W ówczesnej Europie (od XIII w.) stosowana była dla utajnienia treści korespondencji kryptografia. Zygmunt II August używał szyfru w korespondencji ze Stanisławem Hozjuszem ${ }^{15}$. W listach do Radziwilłów nie stosowal szyfru; widocznie nie obawiał się ujawnienia przesyłanych wiadomości.

2.3. Jak w świetle zachowanych listów przedstawia się ostatni przedstawiciel dynastii Jagiellonów, uchodzący - zdaniem niektórych badaczy - za władcę dalekowzrocznego, reformatora, który $w$ życiu osobistym przypomina ostatniego

${ }^{12}$ Listy króla.., nr 5 z 2 II 1548 r. do Mikołaja Rudego, s. 44; nr 17 z 14 VIII 1548 r. do Barbary z Dalejowa Radziwillowej, s. 66; $\mathrm{nr} 39$ z 20 XII 1548 r. do Mikołaja Rudego, s. 102; nr 44 z 11 II 1549 r. do Mikołaja Rudego, s. 109; nr 45 z 27 II 1549 r. do Mikolaja Rudego, s. 110; nr 77 z 24 III 1550 r. do Mikołaja Rudego, s. 160-161; nr 88 do Mikołaja Rudego z 15 VI 1550 r., s. 176; nr 158 z 23 XI 1553 r. do Mikołaja Czamego, s. 287; nr 160 z 22 I 1554 r. do Mikolaja Czarnego, s. 289; nr 168 z 15 III 1554 r. do Mikołaja Czarnego, s. 296; nr 191 z 21 XII 1556 r. do Mikolaja Czarnego, s. 329-330; nr 226 z 6 VI 1562 r. do Mikołaja Rudego, s. 383; nr 238 z 5 XII 1562 r. do Mikołaja Czarnego, s. 396-397; nr 280 z 5 IX 1564 r. do Mikołaja Czarnego, 472-473; nr 281 z 18 IX 1564 r. do Mikołaja Czarnego, s. 473; nr 301 z 28 IX 1565 r. do Mikołaja Rudego, s. 520-521; nr 302 z 13 X 1565 r. do Mikolaja Rudego, s. 521; nr 306 z 20 VII 1566 r. do Mikołaja Rudego, s. 545; nr 322 z 15 VIII 1568 r. do Mikołaja Rudego, s. 545.

is $W$ tych wszytkich rzeczach, w którycheście Ostrowskiego siużebnika swego do nas posiali, jesteśmy mu przed osobq laskawe slyszenie dali. A wyrozumiawszy dobrze to wszystko, co nam imieniem waszym powiedzial, zasie my nieco $k$ 'temu $i$ inne rzeczy imieniem naszym powiedzieć jesteśmy wam przezeń rozkazali, w czym mu wiare dać chciejcie..., ibidem, $\mathrm{nr} 83$ z 26 IV 1550 r. do Mikolaja Rudego, s. 170; zob. też nr 99 z 24 III 1551 r. do Mikołaja Rudego, s. 199; nr 129 z 7 I 1553 r. do Mikolaja Czarnego, s. 249; nr 165 z 19 Il 1554 r. do Mikołaja Czarnego, s. 294; nr 277 z 7 VIII 1564 r. do Mikołaja Czarnego, s. 464; nr 349 z 18 II 1571 r. do Mikołaja Rudego, s. 590.

14 Ibidem, nr 18 z 19 VIII 1548 r. do Mikołaja Rudego, s. 68; nr 40 z 27 XII 1548 r. do Mikolaja Rudego, s. 103; nr 78 z 28 III 1550 r. do Mikołaja Rudego, s. 161; nr 126 z 19 VII 1552 r. do Mikołaja Rudego, s. 242; nr 127 z 3 IX 1552 r. do Mikolaja Rudego, s. 243; nr 134 z 4 Il 1553 r. do Mikołaja Czarnego, s. 256; nr 157 z 16 XI 1553 r. do Mikołaja Rudego, s. 287; nr 173 z 21 V 1554 r. do Mikołaja Czarnego, s. 300; nr 174 z 14 VII 1554 r. do Mikolaja Rudego, s. 301; nr 185 z 30 VI 1555 r. do Mikołaja Czarnego, s. 312; nr 210 z 1 I 1562 r. do Mikolaja Czarnego, s. 355; nr 252 z 13 I 1563 r., s. 426; nr 293 z 3 V 1565 r. do Mikołaja Czarnego, s. 513; nr 304 z 6 XI 1565 r. do Mikołaja Rudego, s. 522; nr 343 z 2 IV 1570 r. do Mikołaja Rudego, s. 578.

15 J. S zy mán ski, Nauki pomocnicze historii, Warszawa 1983, s. 387. 
Piasta na polskim tronie? ${ }^{16} \mathrm{~W}$ korespondencji dominowala problematyka litewska, niemniej jednak poruszano w niej również zagadnienia koronne. Wachlarz poruszanych spraw jest szeroki, co pozwala czytelnikowi zapoznać się $\mathrm{z}$ poglądami monarchy, stwarzając możliwość jego oceny.

3. W sprawowaniu władzy dla rządzącego istotne jest posiadanie informacji. Do ich uzyskiwania Zygmunt II August przywiazzywal bardzo dużą wagę. Żądał od adresatów, aby go informowali o wszystkim. W liście do Mikołaja Rudego z 1 maja 1549 r. nakazuje, abyście do nas o wszytkich rzeczach często i dostatecznie pisywali. Bo acz pan marszalek [Mikołaj Czarny - T. S.] nam dostatecznie pisywać zwykl, jednak my was z tego nie wypuszczamy ${ }^{17}$. $\mathrm{Z}$ zadowoleniem przyjmuje deklarację wojewody trockiego Janusza Jurjewicz Dubrowiecki-Holszańskiego i podskarbiego litewskiego Iwana Ostafjewicz Hornostaja o zamiarze przesyłania wszelkich informacji, które monarsze mogłyby być potrzebne ${ }^{18}$. Z listów wynika, iż otrzymywal je od różnych osób. Chcąc ustawicznie uzyskiwać aktualne wiadomości, nie wyrażał zgody na to, aby Mikołaj Rudy opuszczał Wilno bądź jego okolice ${ }^{19}$, a wy abyście na Wilnie mieszkajqc na wszytki sprawy ludzi $w$ onym państwie naszym żqdamy was, żebyście pilnie trzecie oko chowali [podkreślenie - T. S.], bo widziemy, iz pod tym czasem tam tego jest niemala potrzeba ${ }^{20}$. Równocześnie zdawal on sobie sprawę $\mathrm{z}$ tego, iż dostarczone informacje mogą być subiektywne - mogą ukazywać osoby trzecie w niekorzystnym świetle. Dał temu wyraz $w$ liście do Mikołaja Rudego ${ }^{21}$. Z roli informatorów, jaką

${ }^{16}$ M. Kosman, Zygmunt August, [w:] Życiorysy historyczne, literackie i legendarne, Seria trzecia, red. Z. Stefanowska, J. Tazbir, Warszawa 1992, s. 74; autor tak scharakteryzował Zygmunta II Augusta: Król - myśliciel, wyksztalcony, wybiegajqcy śmialymi koncepcjami daleko naprzód, otoczony szeregiem indywidualności, byl dzieckiem swojej epoki: przejawial zainteresowanie magiq $i$ alchemiq..., ibidem, s. 76.

${ }^{17}$ Listy króla..., nr 50, s. 117. We wcześniejszym liście z 14 III 1549 r. pisał do Mikolaja Rudego: Wy także cobyściekolwiek porozumieli, gdzie by sie tam co takowego trzqść mialo, żqdamy $i$ napominamy was, abyście nam nic nie mieszkajac o wszytkim, cośbykolwiek takowego bylo, znać dawali.., ibidem, nr 47, s. 113.

18. Ibidem.

${ }^{14}$ Abowiem gdy Wilnie i też okolo Wilna mieszkać bedziecie, tedy gdzieby i Iflanty co poczq̨é chcieli, tym tacniej tam mieszkając tego wiadomość mieć bęziecie mogli i potym nam okoto tego sprawe dawać $i$ opatrzenie tym lepsze będzie za życznościq, slużby i czujności waszej; jakoż $i$ inne przyczyny sq, dla których potrzebujemy Wilnie, abo gdzie niedaleko Wilna waszego mieszkania.., ibidem, $\mathrm{nr} 63$ z 11 X 1549 r., s. 131.

20 Ibidem, nr 86 z 3 V 1550 r. do Mikolaja Rudego, s. 174.

${ }^{21}$...w tymże liście swym pisząc nam, co sie tam okolo ni[e]których panów dzieje, tegoście dolożeli, iż cóżbyściekolviek pisali, tedy iż to non ex aliquo odio privato, ale z uprzejmej wiary swej. kiórqście nam powinni, pisywać jesteście zwykli, tedy $w$ tej mierze nie jest potrzeba, abyście sie nam omawiać mieli. [...] Acz jednak byśmy też od was okolo tego wszytkiego żadnej wiadomości nie mieli, jakoż mieć chcemy, tedy nihil esset tam occultum, quin aliquando reveleretur..., ibidem, $\mathrm{nr} 47$, s. 114-115. 
pełnili Radziwillowie, zdawali sobie sprawę współcześni. Wynika to z listownej wypowiedzi, w której Mikołaj Rudy skarżyl się królowi, iż [...] niektórzy [go - T. S.] szpiegiem zowa ${ }^{22}$. Król żądał, aby informowano go o wszystkim, przekazując tak dobre, jak i zle informacje ${ }^{23}$.

W listach spotykamy trzy wzmianki, z których wynika, iż król otrzymuje do wglądu korespondencję pisaną przez osoby trzecie do Radziwiłłów w celu zapoznania się $\mathrm{z}$ ich poglądami ${ }^{24}$. W liście z 30 stycznia $1555 \mathrm{r}$. uspokajal Mikołaja Czarnego, który udostępnil mu taki list, że informacje w nim zawarte nie zostaną nikomu wyjawione. W okresie zamieszania wynikłego z powodu małżeństwa $\mathrm{z}$ Barbarą nakazał Mikołajowi Rudemu, aby przyslal mu listy, jakie otrzymal od wojewody krakowskiego Piotra Kmity, w których Kmita wypowiadal się na temat małżeństwa Zygmunta Augusta $^{25}$. Król polecił, żeby Mikolaj Rudy nakłonił również swoją matkę do udostępnienia mu takich listów. Nie wiemy, co zamierzał w związku z nimi przedsięwziąć.

3.1. Król występowal jako osoba publiczna. W listach nie oddzielał spraw prywatnych od publicznych związanych $\mathrm{z}$ polityką wewnętrzną, jak $\mathrm{i}$ zagraniczną monarchii. Decyzje monarchy nie dają się usystematyzować z punktu widzenia współczesnego prawa państwowego. Każde posunięcie panującego miało charakter publiczny. $Z$ polityką wewnętrzną lączą się zagadnienia związane $\mathrm{z}$ obradami sejmowymi i z zarządem państwa (szeroko rozumianym).

Zagadnienia poświęcone zwołaniu Sejmu, jego obradom poruszone zostały w 86 listach (stanowi to $23,5 \%$ całości listów) ${ }^{26}$.

${ }_{22}^{22}$ Ibidem, nr 91 z 2 VII 1559 r., s. 180.

${ }^{23}$...A jakośmy pierwej $i$ ustnie $i$ przez pisanie nasze TM używali $i$ teraz ponawiamy żqdajqc, abyś nikogo sie nie obawiając (a zwlaszcza nie biorąc tego przedsię, jako nas pisarz nasz Maciej Sawicki sprawil, iże nie śmiesz o tych niebezpiecznych nowinach a prawdziwych nam dostatecznie oznajmować, abyśmy mniemania jakiego na przewloki a stargania sejmu przyszlego na TM nie mieli..., ibidem, $\mathrm{nr} 330$ z 6 XII 1568 r. do Mikołaja Rudego, s. 559.

${ }^{24}$ Ibidem, nr 65 z 24 X 1549 r. do Mikołaja Rudego, s. 136; zob. nr 57 z 3 VIII 1549 r. do Mikołaja Czarnego, s. 124; nr 177 z 30 I 1555 r. do M. Czarnego, s. 304 - król w liście pisal: ...zasie TM list ten odsylamy. A w tym nic watpić nie trzeba, iz to apud nos manebit semper secretum.

${ }^{25} T e \dot{z}$ was żqqdamy i napominamy, abyście nam te wszystkie listy, które byście kolwiek od pana wojewody krakowskiego okolo malżeństwa naszego mieli, poslali, $i$ na to też $i$ matke swq paniq wilenskkq [...] nawiedli, aby takies $[\ldots]$ z waszemi pospolu nam poslala, a zwlaszcza [...] kióremi by jaka chocia też najmniejsza zminka malżeństwa naszego byla uczyniona, bo nam tych listów jest barzo potrzeba, a téz jako inne rzeczy, tak $i$ to jesteście powinniejsi dla nas uczynić..., ibidem, nr 15 z 25 VII 1548 r. do Mikołaja Rudego, s. 62-63; nr 18 z 19 VIII 1548 r., s. 68.

${ }^{26}$ Listy króla.., nr 11, 15, 16, 18, 24, 26, 27, 29, 31, 34, 35, 36, 37, 39, 47, 78, 87, 89, 90, $91,92,94,117,118,120,121,135,137,140,141,159,161,163,165,166,167,178,180$, 
3.1.1. Sprawę egzekucji praw i dóbr - problem ważny $z$ punktu widzenia funkcjonowania państwa szlacheckiego - król poruszył $w$ jedenastu listach, $\mathrm{z}$ tego $\mathrm{w}$ pięciu zostały zawarte szersze wypowiedzi. $\mathrm{Z}$ listu pisanego do Mikolaja Rudego 12 sierpnia 1550 r. wynika, iż monarcha mial świadomość, że postulaty szlachty sprowadzają się do wyegzekwowania przestrzegania przepisów statutów w zakresie rozdawnictwa urzẹdów, królewszczyzn. Wiązało sie to z zastosowaniem sankcji statutowych w stosunku do osób, które otrzymały urzędy, dobra ziemskie $z$ naruszeniem prawa ${ }^{27}$. To, co by w następstwie tak przeprowadzonej egzekucji wróciło do rạk władcy, mógłby on rozdawać podle woli naszej [swojej - T. S.]. Silna presja wywierana przez szlachtę $w$ celu realizacji tych postulatów zdawała się dawać monarsze sposobność, którą mógłby wykorzystać do zreformowania swego państwa. Król uchyla się od podjęcia decyzji. Być może, nie doceniając jego wagi, nie przedstawił w tej materii żadnego programu. Myśmy te egzekucyja na drugi siem zawiesili. Groźbę przeprowadzenia egzekucji wykorzystuje jako narzędzie do przełamania opozycji senatorskiej powstałej w związku ze swym małżeństwem z Barbarą Gasztołdową ${ }^{28}$. Cel doraźny wziął górę nad perspektywicznym. Sprawa egzekucji zostaje poruszona marginalnie w korespondencji wysłanej z sejmu piotrkowskiego $1555 \mathrm{r}$. do Mikołaja Czarnego ${ }^{29}$. Sejm ten mial duże znaczenie $\mathrm{z}$ uwagi na sformułowanie szlacheckiego programu egzekucji, z którym wystąpili posłowie Hieronim Ossoliński i Mikołaj Sienicki. Monarcha obradom sejmowym poświęcil niewiele miejsca, nie ustosunkowal się do programu poselskiego. Znamienne jest zakończenie listu, w którym autor stwierdzal, iż Sejm ten kosztował go wiele zdrowia, czegobyśmy wszytkiego jenak nie żalowali, by tylko to ludziom wdzięczno belo, a izby wżdy nostri labores, które na tych sejmiech podejmujemy non essent vani, a izby beli $z$ pożytkiem państw naszych ${ }^{30}$.

Z sejmu piotrkowskiego 1562/63 r., na którym przystąpiono do egzekucji, pochodzą dwa entuzjastyczne listy Zygmunta II Augusta. Monarcha, informując Mikolaja Czarnego o wynikach obrad, wyrażał zadowolenie, że wieczności i nadania lenne sprzeczne ze statutem $1504 \mathrm{r}$. są nieważne. Powróca do jego dyspozycji, a zastawy, których monarcha nie wykupił,

$181,182,183,186,187,189,190,191,208,209,220,235,240,243,244,246,247,249$, $250,253,265,268,269,270,272,275,279,282,284,285,290,307,321,326,327,329$, $331,332,339,341,342,343,345,346,357,359,360,361$.

${ }^{27}$ Listy króla.., nr 92, s. 186.

${ }^{28}$ Król pisał: ...mnimamy, że ta egzekucyja wiele ich skróci i uskromi, bo sie panom do niej barzo nie chce..., ibidem.

${ }^{29}$ Król dużo więcej uwagi w liście poświęcił sporowi, do którego doszło między żydowskim dzierżawcą wileńskiej mennicy Feliksem a pisarzem mennicy Marcinem Kondratowiczem (24 wersy tekstu), egzekucji poświęcono 1 zdanie (2 wersy), ibidem, nr 182 z 5 VI 1555 r., s. $309-310$.

${ }^{30}$ Ibidem, s. 311. 
bęåą mu również oddane. Posesorzy zastawów, którzy uzyskali wyższe dochody od pożyczki udzielonej królowi, zwrócą nadwyżki do skarbu. Dobra ziemskie oddane będą panującemu, który bẹdzie mógł nimi dysponować ${ }^{31}$. Opinia powyższa rozmijała się z założeniami programu wysuwanego przez Izbę Poselską, dążącą do odzyskania królewszczyzn. Szlachta zamierzała przeznaczyć płynące $\mathrm{z}$ nich dochody na potrzeby państwa, mając nadzieję uwolnienia się $w$ ten sposób od podatków. Król $w$ liście do Radziwilla podkreślał przychylną atmosferę towarzyszącą uchwalaniu konstytucji: ...na żadnym sejmie, na któremeśmy kiedy byli nie pamiętamy, żeby tq zgodq i statecznościq, kiedy i mniejsze rzeczy stanowić, odprawowac sie mogli, jako teraz to nawietsze rzeczy dobra pospolitego, jedno Panie Boze daj, aby tak statecznie wszystko jako sie poczelo i teraz prowadzi do końca przywieść moglo ${ }^{32}$. W kolejnym liście informowal o sprzeciwie posesorów dożywoci, dzierżaw i zastawów na królewszczyznach, którzy nie chcieli z nich zrezygnowac ${ }^{33}$. Poglądy monarchy na egzekucję uległy ewolucji. Po zakończeniu tego sejmu - ku naszemu zdziwieniu - problematyka związana $\mathrm{z}$ egzekucją przestaje być obecna $\mathrm{w}$ listach królewskich. Jest to wielce zastanawiające, jeśli porównamy to milczenie $z$ wielkim optymizmem wyrażanym $w$ dwóch listach $z$ pierwszej połowy grudnia $1562 \mathrm{r}$. W listach pochodzących $z$ następnych sejmów uwaga panującego sprowadzała się do kwestii finansowych, uzyskania uchwały podatkowej ${ }^{34}$. Niewykluczone, że jego aprobata egzekucji, wymuszona okolicznościami (prowadzenie wojny w Inflantach, $z$ czym wiązały się olbrzymie wydatki finansowe), miała charakter formalny, deklaratywny, bez zamiaru przestrzegania podjętych na sejmie postanowień. Król nie akceptowal reform wysuwanych przez ruch szlachecki ${ }^{35}$. Nie potrafil zerwać z Senatem. W wystąpieniach publicznych, sejmowych Zygmunt August oświadczal, że nie zamierza przestrzegać postanowien ograniczających jego władzę rozdawniczą. $\mathrm{Z}$ kwarty przeznaczonej

Ibidem, nr 244 z 6 XII 1562 r., s. 409; nr 247 z 11 XII 1562 r., s. 414-415.

;2 Ibidem, s. 415 .

33 Ibidem, nr 250 z 29 XII 1562 r. do Mikołaja Czarnego, s. 423.

34 Ibidem, nr 263, z 15 III 1563 r. do Mikołaja Czarnego, s. 444; nr 290 z 25 II 1565 r. do Mikolaja Czarnego, s. 507; nr 307 z 23 II 1567 r. do Mikołaja Rudego, s. 525; nr 339 z 2011570 r. do Mikołaja Rudego, s. 570; nr 361 z 22 X 1571 r. do M. Rudego, s. 610. Nie było to nic nowego, gdyż na sejmach przed rokiem 1562 ten wątek był obecny. Na wypowiedż Zygmunta II Augusta, wskazująca m. in. powody zwołania sejmu, natrafiamy w liście do Mikołaja Czarnego napisanym 20 XII 1556 r.: Bo jeśli na sejmie ku obronie się mieć nie bẹda chcieli, iście my niepotrzebnie tam czasu trawić nie bedziemy..., ibidem, $\mathrm{nr} 190$, s. 329; zob. nr 120 z 26 III 1552 r. do Mikolaja Rudego, s. 231; nr 121 z 15 IV 1552 r. do Mikolaja Rudego, s. 233; nr 141 z 30 III 1553 r. do Mikolaja Czarnego, s. 264.

${ }^{35} \mathrm{~T} . \mathrm{Szulc}, Z$ badań nad egzekucjq praw. Podstawy ustawodawcze egzekucji dóbr, ich interpretacja i nowelizacja na sejmach za panowania Zygmunta II Augusta, Studia z Dziejów Państwa i Prawa Polskiego VI, Lódź 2000, s. 50, 61, 64-65, 69, 76, 107-108, 120, 125-127, $140,142,161,166,170-171,177$. 
na obronę potoczną nie rozliczal się, mimo ustawicznych postulatów wysuwanych przez posłów na sejmach.

3.1.2. W swych listach panujący wypowiadał się również $w$ sprawie unii polsko-litewskiej ${ }^{36}$. Wynika $\mathrm{z}$ nich negatywne jego nastawienie wobec unii. Nastawienie to $z$ czasem ulegnie zmianie. Wyrażał niezadowolenie $z$ publicznych wystąpień krajczego litewskiego Jana Radziwiłła nawołującego do zawarcia unii Litwy z Polska $\mathrm{i}$ wprowadzenia na Litwie prawa polskiego ${ }^{37}$. (Uderzały one w jego pozycje jako Wielkiego Księcia Litewskiego). Monarcha opowiadał się za utrzymaniem odrębności obu państw i polecał Mikołajowi Rudemu, aby czynił w tym celu starania wśród szlachty litewskiej ${ }^{38}$. W razie, gdyby $\mathrm{z}$ sejmu koronnego wysłano delegację posłów na Litwę w sprawie rokowań unijnych, chcial uniknąć sytuacji, w której szlachta litewska poparłaby starania delegacji sejmu koronnego w sprawie rokowań unijnych. $Z$ drugiej strony, Zygmunt II August zdawał sobie sprawę, iż zawarcie unii pozwoliłoby na wspólną obronę Litwy i Polski. Dopuszczając tę myśl, uważał, że wówczas unia taka musiałaby być zawarta sub eiusmodi conditionibus i pod takowym ksztaltem, jakośmy z sobq rozmawiali [z Radziwiłłami - T. S. $]^{39}$. Sprzeciwial się zwołaniu wspólnego sejmu, czego domagali się posłowie koronni. Sprawa ta będzie odsuwana $z$ sejmu na sejm. Król zgadzał się natomiast na zwołanie dwóch oddzielnych sejmów, argumentując: Litwa ma swobody, prawa $i$ wolności swe, któreśmy im poprzysiegli, a lamać sie ich nam, czego Boże uchowaj, nie godzi ${ }^{40}$. Proponowal posłom koronnym następujące rozwiązania sprowadzające się alternatywnie do: a) przyjęcia postanowień sejmu wileńskiego przez sejm koronny; b) możliwości wysłania przez sejm koronny przedstawicieli (jednego $z$ senatu, drugiego od izby poselskiej) na sejm litewski; c) zwołania dwóch oddzielnych sejmów - koronnego w Parczowie i litewskiego w Wojnicach - aby namowy wedle potrzeby czynieli.

${ }^{36}$ Informacje o tym są zawarte w listach $\mathrm{nr}: 36,68,75,78,82,91,141,244,253,268,275$, $279,281,284,285,321,327,328,330-334$.

${ }^{37}$ Ibidem, nr 68 z 6 I 1550 r. do Mikołaja Rudego, s. 143; nr 75 z 17 III 1550 r. do Mikołaja Rudego, s. 156-157.

${ }^{38}$ A my też tego zawżdy z powinności naszej postrzegać chcemy $i$ zawżdy będziemy aby księstwo litewskie, które państwo ojczyste nasze jest, tak się dalece $w$ onera korunne nie wlaczalo jakoż $i$ podle statutu korunnego to się dziać nie może. Bo korunne państwo nasze to jest wolne, a ksiestwo nasze litewskie to jest panstwo nasze ojczyste $i$ jest ojczyzna $i$ dziedzictwo nasze. Przetoż panie podczaszy, że to rozumiemy, iż tej unijej fortiter na przyszlym sejmie dochodzić bedq [...] żqdamy was, iżbyście wżdy $w$ onym państwie naszym tak szlachte jako możecie nawieccej sposobiali $i$ ony $k u$ sobie przyciagali, iz gdzieby $k u$ temu przyszio, abyście tam szlachte sibi ad manum zawżdy mieli..., ibidem, $\mathrm{nr} 78$ z 28 III 1550 r., s. $163-164$.

${ }^{39}$ Ibidem, s. 162-163.

${ }^{40}$ Ibidem, nr 141 z 5 III 1553 r. do Mikołaja Czarnego, s. 265. 
Sprawa unii pojawi się w listach, gdy Zygmunt II August przystąpi do egzekucji praw ${ }^{41}$. Według króla, zgodnie $z$ wcześniejszymi ustaleniami z panami litewskimi, miałby być zwołany wspólny sejm na granicy Korony i Wielkiego Księstwa Litewskiego, poprzedzony odrębnym sejmem litewskim. Prosil Mikołaja Czarnego o wskazówki, jak ma się zachować, gdy podczas obrad sejmu koronnego będzie nagabywany o unię $\mathrm{i}$ o wspólny $\operatorname{sejm}^{42}$. Radziwiłłowie, Mikołaj Czarny i Mikolaj Rudy, byli przeciwni zawieraniu unii ${ }^{43}$. Sprawa unii była odkładana $\mathrm{w}$ czasie ${ }^{44}$, mimo poselskich starań ponawianych na poszczególnych sejmach koronnych, od początków panowania Zygmunta II Augusta. Taktyka obstrukcji stosowana przez króla i panów litewskich doprowadzi do stępienia ostrza postulatów szlacheckich ${ }^{45}$. Monarcha nie godził się na postulaty egzekucjonistów zmierzające do zacieśnienia unii na gruncie inkorporacji Litwy do Korony ${ }^{46}$, dążąc do zawarcia związku opartego na zasadzie równości obu partnerów ${ }^{47}$.

${ }^{11}$ Ibidem, nr 253 z 14 I 1563 r. do Mikolaja Czarnego, s. 427.

${ }^{42}$...potrzeba jest, abyś WM [...] nam nic nie omieszkiwają, wypisal $i$ oznajmil, iż gdy ówdzie na tem sejmie koronnem do tego przydzie $i$ nas $w$ tem nachodzić będq $i$ rusza, żebyśmy wiedzieli jako będziem mieć w tem postepować, $i$ gdzie a na który czas ten walny $i$ spólny sejm z Koronq zlożyć, tak żeby przed niem za czasu dojść i skończyć się on pierwszy sejm w Wielkim Ksiestwie Litewskim..., ibidem.

${ }^{43}$ A iz WM te sprawe uniji takowej, która sie na tem sejmie bielskiem stanowić ma, na inem czym jedno niewolq być rozumiejąc jako od moskiewskiego przez moc, tak od panów Polaków per artem; tedy $w$ tem jako wierna rada nasza przestrzegasz nas, a przytem napominasz et obtestaris, przez Pana Boga, z którego wolej jesteśmy tem namiastkiem a pomazańcem Jego, żebyśmy was do takiego wlqczenia a niezlqczenia nie wiedli, gdzie kazde napomnienie WM $u$ nas ossobliwie tak pilne jest dobrze ważne zawsze jako przedniejszej rady naszej..., ibidem, nr 275 z 31 V 1564 r. do Mikołaja Czarnego, s. 460; zob. s. 461; nr 284 z 11 I 1565 r. do Mikołaja Czarnego, s. 483; nr 321 z 9 VIII 1568 r. do Mikołaja Rudego, s. 541-543.

${ }^{44}$ Ibidem, nr 279 z 21 VIII 1564 r. do Mikołaja Czarnego, s. 469; nr 321 z 9 VIII 1568 r. do Mikołaja Rudego, s. 541-542; nr 327 z 1 XII 1568 r. do Mikołaja Rudego, s. 550-551.

${ }^{45}$ Co sie dotycze uniji, o tej tak oznajmujemy WM, wiedzqc że to przy WM zostanie, iż $i$ [posłowie - T. S.] sami $z$ tej strony mierniej już dobrze a skromniej mówiq o niej niż pierwej..., ibidem, nr 282 z 14 XI 1564 r. do Mikołaja Czarnego, s. 474.

16 Różnice poglądów między przedstawicielami Litwy i Korony co do zakresu zespolenia obu państw w ramach unii wyraził nuncjusz papieski G. F. Commendone w liście z 16 II $1564 \mathrm{r}$. do kardynała S. Hozjusza: Lithuani vellent esse duo corpora in unium coniuncta, ut quasi matrimonio copulata Lithuania et Polonia duo essent in carne una; Polonia vellent, ut commiscerentur hac provinciae et coalescerent in unum corpus..., $\mathrm{O}$. $\mathrm{H}$ ale ck $\mathrm{i}$, Dzieje unit jagiellonskiej, t. II: $W X V I$ wieku, Kraków 1920, s. 168, przyp. 2 z odesłaniem do Ms. Czartor. 403, s. 419. Za nim K. Grzybowski, Teoria reprezentacji w Polsce w epoce odrodzenia, Warszawa 1959, s. 38; zob. też J. B a rdach, Zwiqzek Polski z Litwq, [w:] Polska w epoce odrodzenia. Państwo - spoleczeństwo - kultura, red. A. Wyczański, Warszawa 1986, s. 132.

${ }^{47}$...żeby taka unija doszla, jakiej przodkowie polsce i litewscy chcieli; żeby ręka rekke myla etc. I owszem $i$ sami też rozumiemy, żeby takowe unija napotrzebniejsza i napożyteczniejsza być mogla, żeby w zgodzie a milości spólnej $i$ wedla starych spisków $i$ przywilejów, jakośmy wyżej dolożyli doszla, za którq by ręka rẹke myć mogla..., Listy króla..., $\mathrm{nr} 285$ z 11 I 1565 r. do Mikołaja Czarnego, s. 490; nr 321 z 9 VIII 1568 r. do Mikołaja Rudego, s. 541, 543. 
3.1.3. Kwestie związane $\mathrm{z}$ religią, jak i z reformacją, będące przedmiotem obrad sejmowych, w korespondencji poruszano sporadycznie. Król informował Mikołaja Rudego o sporach, do jakich dochodziło między posłami a duchownymi senatorami na tle jurysdykcji sądów kościelnych. W listach $\mathrm{z}$ sejmu piotrkowskiego $1552 \mathrm{r}$. Zygmunt August żalił się, iż spory te pochłaniają wiele czasu, który mógłby być poświęcony na rozwiązanie ważniejszych problemów dotyczących obrony państwa ${ }^{48}$. Podobną wymowę zawierały wypowiedzi króla z sejmu piotrkowskiego z roku $1555^{49}$. Król nie angażował się $w$ spory religijne po żadnej ze stron. Monarcha sprzeciwial się postępowaniu kaznodziejów głoszących nowinki reformacyjne, gdy wkraczali w obowiązki należące do kościoła katolickiego. Nakazywał Mikołajowi Rudemu, aby ten poskromil ich w prowadzeniu niepotrzebnych dysputacyi [...], iżby tak sobie na stronie żyli $i$ też nie kazywali $i^{50}$. Poleca jednak czynić to bardzo ostrożnie, aby ich nie spłoszyćs ${ }^{51}$. Do szerzenia Reformacji król - jak się wydaje - miał jednak stosunek ambiwalentny. Na wiadomość o tym, iz ksiądz Koźmin ustawicznie wojewodzie $i$ wojewodzinej wileńskiej [Janowi i Hannie Hlebowiczom] coś w ucho szepce, odpowiedzial w liście: ...tedy niechaj juz szepce, to nas iście nic nie rusza ${ }^{52}$.

3.1.4. Groźba bezdzietnego zejścia króla czyniła aktualną sprawę uregulowania następstwa tronu po Zygmuncie II Auguście. Wątek ten pojawia się $w$ trzech zaledwie listach. W trakcie obrad sejmu piotrkowskiego 1558/59 r. podjęto akcje przeglądania przywilejów i statutów Królestwa pod kątem ich zgodności z prawem. Wówczas - jak pisał król do Mikołaja Czarnego - przyszlo de electione regis ruszyć, tedyśmy sami podali, aby namawiali modum eligendi regis ${ }^{53}$. Posłowie byli zadowoleni, gdyż $w$ ten sposób ukręcono by glowę plotkom o tajnych układach króla $\mathrm{z}$ cesarzem w sprawie następstwa tronu ${ }^{54}$. Do elekcji król nie powraca w listach aż do $1570 \mathrm{r}$.

${ }^{48}$ Ibidem, nr 118 z 10 Il 1552 r. do Mikołaja Rudego, s. 229; nr 220 z 26 III 1552 r. do Mikołaja Rudego, s. 231.

${ }^{49} J u \dot{z}$ to cztery niedziele strawieliśmy na religiej, a ine wszytki potrzebne rzeczy, dla których się sejm zlożel, zaniechane leża; $i$ już tego zdrowiem barzo przyplacamy, bo nam przyszedl jakis fluks $w$ reke $z$ wielkim bólem, ześmy już kilka nocy nie spali..., ibidem, $\mathrm{nr} 181$ z 21 V 1555 r. do Mikołaja Czarnego, s. 308. Królowi zależało wówczas bardzo na decyzjach odnoszących się do udzielenia pomocy Litwie, z uwagi na wygasający termin rozejmu z Wielkim Księstwem Moskiewskim. Zob. nr $180 \mathrm{z} 13 \mathrm{~V} 1555 \mathrm{r}$. do Mikołaja Czarnego, s. 306-307.

so Ibidem, nr 15 z 25 VII 1548 r. do Mikołaja Rudego, s. 62.

s! ...wszakoż je cudnemi a lagodnemi slowy ujmujcie, aby się wżdy jadnak nie uploszyli..., ibidem, nr 15 z 25 VII 1548 r. do Mikołaja Rudego, s. 62.

52 Jbidem, s. 62.

53 Ibidem, nr 199 z 3 I 1559 r., s. 339.

54 Ibidem, nr 200 z 6 I 1559 r. do Mikołaja Czarnego, s. 340. 
W liście z 2 kwietnia 1570 r. do Mikołaja Rudego, ostatni Jagiellon uchyla się od wypowiadania się w sprawie bezkrólewia, pozostawiając je do rozstrzygnięcia sejmowi ${ }^{55}$. Zagadnienie to zostało poruszone $w$ legacjach na sejmiki przedsejmowe. Król zdawał sobie sprawę z zagrożeń wynikających $z$ tego stanu rzeczy ${ }^{56}$, jednakże nie poparł starań mających na celu rozstrzygnięcie tego problemu jeszcze za jego życia. Ten brak poparcia uniemożliwił powzięcie jakichkolwiek decyzji.

3.2. Jednym $z$ pierwszych problemów, $z$ którym zetkną się młody monarcha obejmując władzę, była, wywołana małżeństwem z Barbarą Gasztołdową, ostra opozycja senatorsko-szlachecka, której przewodziła królowa Bona. Z listów wynika, iż Zygmunt II August byl poinformowany, którzy z dostojników, urzędników królewskich byli wobec niego w opozycji ${ }^{57}$. Król chciał doprowadzić do izolacji swoich przeciwników. Jednym z opozycjonistów był wojewoda krakowski Piotr Kmita. Zygmunt II August nakazal więc Mikołajowi Rudemu i jego matce, aby nie wdawali się $w$ wielka nazbyt praktyke albo przyjaźń $z$ wojewodq krakowskim, albowiem stqd się znaczy, jakim jest domu waszego przyjacielem, gdyż w wystąpieniach przeciw Zygmuntowi Augustowi podżega go królowa Bona wraz $z$ kasztelanem krakowskim Janem Tarnowskim ${ }^{58}$. Gdy wojewoda krakowski zaprosił Mikołaja Rudego, król polecil, aby Mikołaj wymówił się. Doradzał: ...abyście sobie raczej jakq niemoc abo chorobe zamyślili, niźli żeby tam do niego jechać, abo [...] gdzie widzieć [z nim - T. S.] mięli ${ }^{59}$. Wkrótce jednak zmienil zdanie i tak instruował Mikołaja Rudego, ma: ...więcej sluchać niżli k'czemu sie wiadomościq swa przymawiać raczył ${ }^{60}$. W ten sposób monarcha chcial dowiedzieć się o zamiarach przeciwnika ${ }^{61}$ : donoszono mu o spotkaniach jego politycznych przeciwników, a także o ich dzialaniach ${ }^{62}$. Rozeznanie

${ }^{5}$ De interregno [...] to nie nasza sprawa dywinowac zbytnie, o tym bedziecie WM wszyscy sami okolo tego na sejmie namawiać..., ibidem, nr 343, s. 576-577.

s6 Ibidem, s. 578.

57 Ibidem, nr 14 z 25 VI 1548 r. do Mikołaja Rudego, s. 58; nr 27 z 9 XI 1548 r. do Mikołaja Rudego, s. 82; nr 36 z 6 XII 1548 r., s. 97.

58 Ibidem, nr 15 z 25 VII 1548 r., s. 64.

Ibidem, nr 24 z 24 X 1548 r., s. 77. W liście do Mikołaja Rudego z 2 VII 1550 r. wyrażał zadowolenie, iż ten przekonał wojewodę witebskiego Stanisława Kiszkę, aby nie spotkał się z kasztelanem trockim Hieronimem Chodkiewiczem, ibidem, nr 91, s. 181; zob. też nr 95 z 15 X 1550 r., s. 194.

so Ibidem, nr 41 z 14 I 1549 r., s. 104.

${ }^{61}$ Ze spotkania Mikołaj Rudy zdał królowi listowną relację, ibidem, nr 42 z 26 I 1549 r., s. 105.

62 Barzo nam to wdzięczno jest, iżeście nam drugimi swoimi listy dali znać okolo tego zjachania, trzy mile od Kowna pana wileńskiego [kasztelan wileński Wirszył Grzegorz Ościkowicz] $z$ panem trockim [kasztelan trocki Hieronim Chodkiewicz], ibidem, nr 91 z 2 VII 1550 r. do Mikołaja Rudego, s. 182; zob. nr 86 z 3 V 1550 r. do Mikołaja Rudego, s. 173-174; zob. również: nr 26 z 2 XI 1549 r., s. 8I; nr 47 z 14 III 1549 r., s. 113; nr 78 z 28 III 1550 r., 
w nastrojach elity politycznej ułatwiało władcy podejmowanie decyzji. W liście do Mikolaja Rudego z 14 marca 1549 r. pisał: Snać będziemy dobrze wiedzieć potym, jako laska nasza szafować i jako komu authoritatem, podle laski naszej uzyczać bedziem mieli ${ }^{63}$. Monarcha nie życzył sobie przyjazdu na akt zlożenia holdu lennego przez książąt pomorskich - krajczego litewskiego Jana Radziwiłla i stolnika litewskiego Stanisława Kieżgajło. Jako że pozostawali oni w opozycji, król obawiał się, iż swoimi wypowiedziami zakłócą uroczystość ${ }^{64}$.

Kasztelan wileński Grzegorz Wirszyłł Ościkowicz swym postępowaniem naraził się Zygmuntowi Augustowi. W związku z zapowiedzianym przybyciem kasztelana do Piotrkowa, król postanowił okazać mu swoją niełaskę. W liście z 2 lipca $1550 \mathrm{r}$. do Mikołaja Rudego pisał: ...będzie li $z$ nami [Wirszył - T. S.] chcial okolo takowych rzeczy, jakoście nam pisali rozmowy jakie mieć, uslyszeć na wszytko takowq odpowiedź, po którq mógl tu tak daleko nie jeździć. Nie pomożé mu to nic, chociaby tu skąd otuche mial już my sami temu dosyć uczyniemy, że go odprawiemy, tak jako bedzie przystalo. A ostatek mu do przyjachania naszego do Litwy zawiesiemy ${ }^{65}$. W analogiczny sposób zamierzał postạpić z kasztelanem trockim Hieronimem Chodkiewiczem $^{66}$. Wobec uwagi Mikołaja Rudego, iż obaj kasztelanowie, dla osiągnięcia zamierzonych celów, będą wywierali presję na króla, ten odpowiedzial, iż to już wcześniej próbowali czynić panowie koronni, lecz im siẹ to nie udało.

W listach pisanych z sejmu piotrkowskiego z $1550 \mathrm{r}$. do Mikołaja Rudego król informowal o zmianie nastawienia do niego opozycyjnych senatorów, którzy usiłują wrócić do lask królewskich ${ }^{67}$.

s. 163; nr 82 z 23 IV 1550 r., s. 168; nr 135 z 11 II 1553 r., s. 256-257. Gdy do Warszawy przyjechał biskup żmudzki Wacław Wierzbicki, osoba należąca do opozycji, utrzymująca kontakty z Boną, król polecil dowiedzieć się o celu jego przyjazdu, Wy się tam o to napilniej przyczyniajcie, abyście się dowiedzieć mogli, a gdy przyjedzie, nie wadzieloby mu o to uszu slowy natrzeć..., ibidem, nr 47 z 14 III 1549 r. do Mikolaja Rudego, s. 114.

${ }^{63}$ Ibidem, nr 47, s. 113.

64 Ibidem, nr 57 z 3 VIII 1549 r. do Mikołaja Czarnego, s. 125; zob. nr 70 z 31 I 1550 r. do Mikołaja Rudego, s. 144 - odnośnie do udziału stolnika litewskiego Stanisława Kieżgajłła na weselu księcia pruskiego Albrechta.

6s Ibidem, nr 91, s. 182-183. W liście do Mikołaja Rudego z 17 III 1550 r. król w tajemnicy stwierdził, iż nosi się z zamiarem pozbawienia Jana Radziwiłła starostwa tykocińskiego: Lecz panie podczaszy to juz wam w tym confidenter intencyja swoje oznajmujemy. Że my Tykocin, który krajczy do laski naszej ma, jemu z ręku już wziqusć chcemy, gdyż sie mu zda tak innych laska być ważniejsza i pożyteczniejsza, niż nasza, pana swego..., ibidem, nr 75, s. 157.

${ }^{66}$ A iż téz pan trocki tu jedzie dla wlók, cywunistw i dla innych przyczyn, jakoście nam pisali, ale też jadq z nim trzej tyw[u]nowie. A tak i to sie barzo baczno odprawi abowiem to wszytko do Litwy odlożemy, bośmy my to nie zwykli, w Korunie mieszkajac, potrzeb ziemskich onego pañstwa naszego sprawować..., ibidem, nr 91, s. 183.

${ }^{67}$ Ibidem, nr 89 z 20 VI 1550 r., s. 176-177; nr 91 z 2 VII 1550 r., s. 184; nr 92 z 12 VIII 1550 r., s. $185-186$. 
3.3. W listach były także poruszane sprawy związane z zarządem państwa.

3.3.1. Na temat powołań na opróżnione urzędy w Wielkim Księstwie Litewskim Zygmunt II August zasięgal zdania Mikołaja Rudego albo Mikołaja Czarnego. W listach napotykamy informacje o nominacjach na urzędy: wojewody, starosty, kasztelana, krajczego litewskiego, ciwuna (tywuna), horodniczego, pisarza hospodarskiego również na inne, niższe (w tym także kościelne) ${ }^{68}$. Natrafiamy na dwie wzmianki odnoszące się do urzędów koronnych. Pierwsza dotyczyła godności marszałka wielkiego koronnego i wojewody krakowskiego (?), które zawakowały po śmierci Piotra Kmity ${ }^{69}$. Król pierwotnie zamierzał powierzyć urząd marszałka wielkiego koronnego Stanisławowi Tęczyńskiemu wojewodzie sandomierskiemu, którego uważal za najsposobniejszego do jego sprawowania. Odstąpił jednak od tego zamiaru, gdyż kasztelan krakowski Jan Tarnowski usilnie wstawiał się za Janem Mieleckim - swym siostrzeńcem. Mimo że Jan Tarnowski nie cieszył się względami monarchy, ten jednak przychylił się do jego prośby. Zadecydował o tym fakt, że król w obliczu zbliżającej się wojny z Moskwą potrzebowal pomocy Tarnowskiego, którego tą nominacją pragnął pozyskać; nie chciał ponadto go drażnić, bowiem - jak monarsze doniesiono - gdyby się lada ocz rozgniewal p. krakowski, ut fit, $i$ sam by nie jachal [na wyprawę przeciw Moskwie - T. S.], i podobno by $i$ wojewodzie podolskiemu jachać zakazafo ${ }^{0}$ Z ostateczną decyzją król zamierzal się wstrzymać do chwili uzyskania od Mikołaja Czarnego odpowiedzi w tej sprawie. Druga wzmianka

58 Ibidem, nr 11 z 2 VI 1548 r. do Mikołaja Rudego, s. 53; nr 12 z 2 VI 1548 r. do Barbary Gasztoldowej, s. 55; nr 14 z 26 VI 1548 r. do Mikolaja Rudego, s. 59; nr 38 z 20 XII 1548 r. do Mikołaja Rudego, s. 101; nr 43 z 11 II 1549 r. do Mikołaja Rudego, s. 108; nr 49 z 21 III 1549 r. do Mikołaja Rudego, s. 116; nr 50 z 1 V 1549 r. do M. Rudego, s. 117; nr 51 z 16 V 1549 r. do Mikołaja Czarnego, s. 118; nr 56 z 31 VII 1549 r. do Mikołaja Czarnego, s. 123; nr 91 z 2 VII 1550 r. do Mikołaja Rudego, s. 181-182; nr 103 z 6 V 1551 r. do Mikołaja Rudego, s. 204; nr 110 z 4 VI 1551 r. do Mikołaja Rudego, s. 212 ; nr 161 z 30 I 1554 r. do Mikołaja Czarnego, s. 290; nr 164 z 16 II 1554 r. do Mikołaja Czarnego, s. 293; nr 169 z 16 III 1554 r. do Mikołaja Rudego, s. 297; nr 179 z 20 IV 1555 r. do Mikołaja Rudego, s. 306; nr 181 z 21 V 1555 r. do Mikołaja Czarnego, s. 308 ; nr 183 z 30 VI 1555 r. do M. Czarnego, s. 312; nr 186 z 30 X 1556 r. do Mikołaja Czarnego, s. 318; nr 187 z 20 XI 1556 r. do Mikolaja Czarnego, s. 319, 322; nr 208 z 23 XII 1561 r. do Mikołaja Czarnego, s. 350, 351; nr 209 z 29 XII 1561 r., s. 352-353, 354; nr 320 z 13 IV 1568 r. do Mikołaja Rudego, s. 540.

${ }^{69}$ Ibidem, nr 181 z 5 VI 1555 r. do Mikołaja Czarnego (Stanisław Tęczyński otrzymal urząd wojewody krakowskiego), s. 308; zob. nr 165 z 19 II 1554 r.: Cośs nam TM pisal cedule swa ręka, my tych wakancyjej, tak jakośmy z TM o tym mówieli w Knyszynie, nie mamy woli rozdać aż na samym końcu sejmu, wyjqwszy iżby tego potrzeba ukazowala. Ale to pewna, że wojewodzie lubelskiemu [Andrzej Tęczyński] województwa nie damy, s. 294.

70 Ibidem, nr 181, s. 309; zob. W. D wor z a cze k, Hetman Jan Tarnowski. Z dziejow możnowladztwa malopolskiego, Warszawa 1985, s. 190-191. 
odnosiła się do obsady urzędu kasztelana sandomierskiego po śmierci Mikołaja Wolskiego ${ }^{71}$.

Do spraw związanych $\mathrm{z}$ zarządem należały również te, które łączyły się ze sprawowaniem namiestnictwa przez Mikolaja Rudego Radziwiłła pod nieobecność króla na Litwie, a namiestnictwo oznaczało ciągle przebywanie w Wilnie. Zygmunt II August nie zgadzał się na prośby Radziwiłla, gdy ten chcial wyjechać do swoich dóbr czy do Korony ${ }^{72}$, nakazując mu przebywać ustawicznie $w$ Wilnie bądź $w$ pobliżu, tak by mógł osobiście wypełniać zlecone mu obowiązki. Nie pozwolił mu na opuszczenie Wilna nawet $\mathrm{z}$ okazji uroczystości swoich zaślubin $\mathrm{z}$ Katarzyną Habsburżanką ${ }^{73}$. Podobnie król nie zgodził się na udział Stanisława Stanisławowicza Dowojno, wojewody połockiego, w pospolitym ruszeniu zwołanym przeciwko Tatarom. Pod jego bowiem pieczą znajdowały się zamki pograniczne ${ }^{74}$. Wyrażał dezaprobatę, gdy któryś $\mathrm{z}$ wojewodów czy starostów opuszczal miasto będące siedzibą województwa czy starostwa ${ }^{75}$.

3.3.2. Gdy dochodziło do sporów między urzędnikami, król podejmował próby pogodzenia zwaśnionych stron. $Z$ listów dowiadujemy się o sporze między hetmanem wielkim koronnym Janem Tarnowskim a wojewodą krakowskim Piotrem Kmitą ${ }^{76}$; między wojewodą wileńskim Mikolajem

$"$ Pan sandomierski jako dziś trzeci dzień umarl, gdzie po nim bonum et pingue beneficium vacat, panu Janowi [Radziwiłlowi - T. S.] krajczemu naszemu litewskiemu, Listy króla..., nr 10 z 17 V 1548 r. do Mikołaja Rudego, s. 51; odnośnie do obsady urzędu zob. nr 11 z 2 VI 1548 r., s. 53.

${ }^{72}$ Sporadycznie zezwalał mu na krótkie wyjazdy możecie sie czasem przejeżdżawać do Trok $i$ do innych dworów bliższych Wilna, tak iżbyście wżdy mogli, kiedy by potrzeba byla hnet do Wilna nadbieżé, bosmy tak pisali, aby żadne ziemskie sprawy przez was nie byly sprawowany, ibidem, nr 50 z 1 V 1549 r. do Mikołaja Rudego, s. 117; nr 51 z 16 V 1549 r. do Mikołaja Czarnego, s. 119; nr 93 z 20 VIII 1550 r. do Mikolaja Rudego, s. 187; nr 122 z 20 V 1552 r. do Mikołaja Rudego, s. 236; nr 145 z 11 V 1553 r. do Mikolaja Rudego, s. 270.

${ }^{73}$ Ibidem, nr 145 z 11 V 1553 r. do Mikolaja Czarnego, s. 270.

${ }^{74}$ Ibidem, nr 70 z 31 I 1550 r. do Mikołaja Rudego, s. 146.

${ }^{75}$ Ibidem, nr 73 z 28 II 1550 r. do Mikołaja Czarnego, s. 153; nr 80 z 14 IV 1556 r., s. 166; nr 190 z 20 XII 1556 r. (zezwolenie na wyjazd), s. 328; nr 207 z 20 XII 1561 r., s. 348; nr 211 z 5 I 1562 r., s. 357; nr 247 z 11 XII 1562 r., s. 413 ; nr 264 z 15 III 1563 r., s. 445. Król wyznacza zastępcę na urząd wojewody kijowskiego, który miał być nieobecny, z uwagi na planowaną wyprawę wojewody kijowskiego Konstantego Wasyla Ostrogskiego na państwo moskiewskie, ibidem, nr 274 z 26 IV 1564 r. do Mikołaja Czarnego, s. 458. Zob. również nr 293 z 3 V 1566 r. do Mikołaja Czarnego, s. 512. W liście do Mikołaja Rudego z 6 V 1548 r. król wyraża zdziwienie, iż starosta merecki Stanisław Dowojno, któremu powierzono opiekę nad Barbarą Gasztołdową od królowej Jej $M$ odjechal, czego nieradzi widzimy. A tak nam dajcie znać coby za przyczyna tego byla..., ibidem, nr 8, s. 49.

${ }^{76}$ Ibidem, nr 2 z 8 XII 1547 r. do Mikołaja Rudego, s. 40-41; nr 15 z 25 VII 1548 r., s. 61. Zob. W. D worzaczek, Hetman Jan Tarnowski.., Warszawa 1985, s. 141. 
Czarnym Radziwiłłem a jego bratem krajczym litewskim Janem ${ }^{77}$; miẹdzy starostą czerkaskim Dymitrem Wiśniowieckim a starostą rozbickim (postać nieznana $)^{78}$; między Barbarą z Kolów Radziwilłową matką Mikolaja Rudego a marszałkiem wielkim koronnym Janem Mieleckim (powinowatym Radziwillów) ${ }^{79}$. Starania nie zawsze kończyły się wyciszeniem konfliktu. Spory takie były szkodliwe $\mathrm{z}$ punktu widzenia interesów monarchy, albowiem zaangażowanie się króla po którejkolwiek ze stron powodowało przejście strony niezadowolonej do opozycji antykrólewskiej. Zygmunt II August pośredniczył w sporze między dzierżawcą mennicy wileńskiej Feliksem a jej pisarzem ${ }^{80}$; angażował się też w sprawę rozwodową Mikołaja Rudego ${ }^{81}$.

3.3.3. W listach poruszane były sprawy związane ze skarbowością litewską (wzmianki o wybieraniu $\mathrm{m}$. in. podatku gruntowego serebczyzny ${ }^{82}$, $\mathrm{cla}^{83}$, myta $\left.^{84}\right)$.

3.3.4. W niektórych listach znajdujemy ustępy tekstu poświęcone sprawom z zakresu wymiaru sprawiedliwości ${ }^{85}$. Z powodu nadużyć król odwohuje starostę braclawskiego Stanisława Jakubowicz Skopa, nakazując przeprowadzenie dochodzenia komisji z Mikolajem Rudym na czele ${ }^{86}$.

O sprawiedliwość zwracają się do króla osoby z jego otoczenia, poszkodowane przez osoby trzecie. Takim zainteresowanym był dworzanin królewski

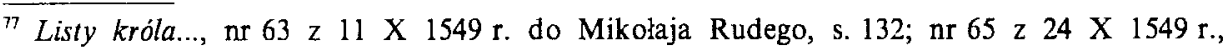
s. 136-137; nr 70 z 31 I 1550 r., s. 146; nr 72 z 16 II 1550 r., s. 150-15I; nr 75 z 17 III 1550 r., s. $156-157$; nr 78 z 28 III 1550 r., s. 162.

${ }^{78}$ Ibidem, nr 124 z 16 VI 1552 r. do Mikołaja Rudego, s. 239.

${ }^{79}$ Ibidem, nr 15 z 25 VII 1548 r. do Mikołaja Rudego, s. 63-64; nr 18 z 19 VIII 1548 r, s. 68; nr 21 po 19 VIII przed 1 IX 1548 r. do Barbary z Dalejowa Radziwiłłowej, s. 74; nr 42 z 26 I 1549 r. do Mikolaja Rudego, s. 105-106; nr 47 z 14 III 1549 r., s. 112; nr 68 z 6 I 1550 r., s. 142 ; nr 72 z 16 II 1550 r., s. 148-150; nr 78 z 28 III 1550 r., s. 161, 162.

xo Ibidem, nr 182 z 5 VI 1555 r. do Mikolaja Czarnego, s. 309-310.

${ }^{81}$ Ibidem, nr 124 z 16 VI 1552 r. do Mikołaja Rudego, s. 240; nr 125 z 16 VII 1552 r., s. 241; nr 145 z 11 V 1553 r. do Mikołaja Czarnego, s. 271.

82 Ibidem, nr 66 z 13 XII 1549 r. do Mikolaja Rudego, s. 140; nr 94 z 19 IX 1550 r., s. 191, 192; nr 138 z 9 III 1553 r., s. 260; nr 143 z 25 IV 1553 r., s. 269; nr 185 z 26 X 1556 r. do Mikolaja Czarnego, s. 313-314; nr 187 z 20 XI 1556 r., s. 320; nr 189 z 12 XII 1556 r., s. 325; nr 319 z 13 III 1568 r. do Mikołaja Krzysztofa Sierotki, s. 538.

s; Ibidem, nr 103 z 6 V 1551 r. do Mikołaja Rudego, s. 204; nr 337 z 31 XII 1569 r., s. 567; nr 340 z 30 I 1570 r., s. 571.

${ }^{84}$ Ibidem, nr 343 z 2 IV 1571 r. do Mikołaja Rudego, s. 579.

${ }^{85}$ Ibidem, nr 47 z 19 III 1549 r. do Mikołaja Rudego, s. 114; nr 51 z 16 V 1549 r. do Mikołaja Czarnego, s. 120; nr 75 z 17 III 1550 r. do Mikołaja Rudego, s. 158; nr 140 z 25 III 1553 r., s. 263; nr 143 z 25 IV 1553 r., s. 268; nr 179 z 20 IV 1555 r., s. 306; nr 186 z 30 X 1556 r. do Mikołaja Czarnego, s. 317-318; nr 209 z 29 XII 1561 r., s. 355.

xo Ibidem, nr 65 z 24 X 1549 r. do Mikołaja Rudego, s. 138; nr 66 z 13 XII 1549 r., s. 140; nr 67 z 2 I 1550 r., s. 141; nr 70 z 31 I 1550 r., s. $144-145$; nr 72 z 16 II 1550 r., s. 151. 
Jarosz Korycki - koniuszy litewski. Pod jego nieobecność, dobra ziemskie należące doń były pustoszone, a poddani krzywdzeni przez niejakich Ostrowickiego i Welmeńskiego (postacie nieznane). W rezultacie wladca nakazał Mikołajowi Rudemu, aby dopilnował naprawienia szkód przez sprawców ${ }^{87}$.

$\mathrm{O}$ interwencje króla prosił jego balwierz Ludwik Verad z Ferrary, którego ludzi pobił i konie im zabrał Tomkowicz (osoba nieznana). I w tym przypadku władca nakazał Mikołajowi Rudemu wymierzyć sprawiedliwość, a mienie skarżącego chronićs ${ }^{88}$.

Podobnie było $w$ przypadku sporu o jakąś sumę pieniędzy między Janem Pokrzywnickim (postać nieznana) a puszkarzem królewskim Pawłem ${ }^{89}$.

$\mathrm{Na}$ prośbę strony król ingeruje $w$ tok wymiaru sprawiedliwości. Zwrócił się do Mikołaja Rudego, który miał sądzić sprawę, aby TM jego sprawy tyle, ile sprawiedliwość poniesie u siebie mieć zalecone raczylpo.

$\mathrm{O}$ wyrażenie zgody na aresztowanie sprawcy przestępstwa prosił króla Mikołaj Rudy. Tak było w przypadku zabójstwa jego dworzanina przez mieszczanina Tomasza Krolczyca ${ }^{91}$. Nie wiemy, czy interwencja u króla była podjęta $\mathrm{z}$ inicjatywy samego wojewody czy wskutek zwrócenia się krewnych zamordowanego o pośrednictwo wojewody. Król zadośćuczynił prośbie.

Spotykamy się jednak również $\mathrm{z}$ odmową spełnienia prośby Mikołaja Rudego wstawiającego się za swoim dworzaninem Boguszem Koszką, który został pobity ${ }^{92}$; nie znamy ani okoliczności sprawy, ani motywów decyzji monarszej.

W korespondencji znaleźć można przypadek naruszający ewidentnie zasady wymiaru sprawiedliwości. Przykładem tego była sprawa Lobockiego (dawny dworzanin Mikołaja Rudego (?), postać nieznana). Lobocki wypowiadał się publicznie o monarsze bardzo obraźliwie ${ }^{93}$. Nie było to jego pierwsze wystąpienie. Król poleca przeprowadzić dochodzenie. Gdyby ono wykazało, iż rzeczywiście wymieniona osoba tak się zachowywała, jak mu doniesiono, proponowal jedno $\mathrm{z}$ dwóch rozwiązań. Pierwsze: znaleźć sposób i ostrożnie, bez hałasu (caute, aby to sine tumultu), pozbyć się Lobockiego, aby ten [...] więcej na świecie nie mieszal. Król nie wahał się zaproponować drastyczny środek, jakim jest pozbawienie życia. Świadczy to zarazem o ogromnym zaufaniu, jakie żywił do Radziwiłła. Drugie - o charakterze

${ }^{87}$ Ibidem, nr 74 z 14 III 1550 r., s. 154 .

${ }^{88}$ Ibidem, nr 76 z 19 III 1550 r., s. 159.

${ }^{89}$ Ibidem, nr 119 z 12 III 1552 r. do Mikołaja Rudego, s. 229-230.

${ }^{90}$ Ibidem, nr 130 z 10 I 1553 r., s. 247.

91 Ibidem, nr 15 z 25 VII 1548 r., s. 64; nr 18 , z 19 VIII 1548 r., s. 70.

92 Ibidem, nr 91 z 2 VII 1550 r., s. 181.

43 ...iż on Lobocki [...] teraz w tych czasiech w Drohiczynie będac, mial byl snać wszczqć niejakie bardzo nieprzystojne a snać dignitatem Mtis nostrae obrażajqce rozmowy [...] to tego Lobockiego tam wszeteczne, a nieprzystojne mówienie, iż nas niepomalu obraża, chcemy aby pierwej inkwizycyja [...] przeprowadzić, ibidem, nr 9 z $14 \mathrm{~V} 1548$ r. do Mikołaja Rudego, s. 50. 
umiarkowanym. Podczaszy litewski miałby przyjąć go na służbę, podczas której, znając charakter osoby - zdaniem monarchy $-\mathrm{z}$ pewnością nadarzy sie okazja, aby swa stad zaplate [...] mógl wziqusć. Zygmunt August nakazywał Mikołajowi Rudemu, aby $z$ wielkq pilnościa zajął się tą sprawą. Nie jest nam znany jej końcowy wynik.

Inaczej zareagował władca, gdy Mikołaj Rudy poskarżył się na kasztelana wileńskiego Grzegorza Wirszyła, który w obecności innych osób wyrażał się obelżywie o Radziwille. Król złożył to na karb szaleństwa ${ }^{94}$. Wnioskował, aby Radziwilł znalazł osoby, które chciałyby zeznawać jako świadkowie, i wytoczył sprawę przed sądem królewskim. Radził zarazem mu uzbroić się w cierpliwość i skorzystać z pomocy przyjaciół; być może Wirszył w ich obecności nieprzystojnie będzie się również wypowiadal. Wówczas, gdy Zygmunt August przyjedzie na Litwę, będzie można pozwać kasztelana do sądu. Prawdopodobnie Mikołaj Rudy zastosował się do powyższych rad, gdyż $w$ kolejnym liście król pisał, iż jeśli Wirszył tylko w kacie śmialy, $a w$ oczy nic nie mówi, to sprawę należy odłożyćss.

3.3.5. Królowi przysługiwało prawo i obowiązek opieki nad wszystkimi, którzy jej potrzebowali. Monarcha zajmowal się losem rodzin po zmarłych wojewodach, starostach, pogrzebem pozostałych po nich wdów ${ }^{96}$. Z tytułu opieki decyduje o losie pozostałego przy życiu małżonka, ich dzieci, dóbr ${ }^{97}$. I tak po śmierci wojewody wileńskiego Jana Jurjewicz Hlebowicza postanowil, iż dwór po zmarlym należy się jego dzieciom z pierwszego małżeństwa ${ }^{98}$.

Przeciwny był planom zawierania przez podlegających jego opiece związków małżeńskich bez jego aprobaty, czy sprawowaniu pieczy przez krewnych $z$ naruszeniem jego uprawnień ${ }^{99}$. Dużo uwagi pochłonęła sprawa wdowy po księciu Ilii Ostrogskim, staroście bracławskim i winnickim, Beaty. z Kościeleckich Ostrogskiej i jej córki Elżbiety, której zwierzchnim opiekunem byl król ${ }^{100}$. Sprawa ta występuje w listach $z$ lat $1550-1559$. Elżbieta Ostrogska,

\footnotetext{
94 Ibidem, nr 47 z 14 III 1549 r. do Mikolaja Rudego, s. 114.

95 Ibidem, nr 51 z 16 V 1549 r. do Mikolaja Czarnego, s. 119.

${ }^{96}$ Ibidem, nr 63 z 11 X 1549 r. do Mikołaj Rudego, s. 132-133.

${ }^{97}$ Ibidem, nr 51, z 16 V 1549 r. do Mikolaja Czarnego, s. 120; nr 65 z 24 X 1549 r. do Mikołaja Rudego, s. 137; nr 66 z 13 XII 1549 r., s. 139; nr 68 z 6 I 1550 r., s. 142; nr 127 z 3 IX 1552 r., s. 243. Odnosiło się to również do innych.

${ }^{98}$ Ibidem, nr 65 z 24 X 1549 r. do Mikołaja Rudego, s. 137; nr 68 z 6 I 1550 r., s. 142.

${ }_{99}$ Ibidem, nr 94 z 19 IX 1550 r. do Mikołaja Rudego, s. 192; nr 121 z 15 IV 1552 r., s. 235; nr 122 z 20 V 1552 r., s. 237 ; nr 125 z 16 VII 1552 r., s. 241.

100 Ibidem, nr 80 z 14 IV 1550 r. do Mikolaja Czarnego, s. 166; król w liście do Mikołaja Czarnego z 10 II 1552 r. pisal: Zda się nam, aby JM księciu Konstantemu Wasilewi pisal, iż by księżnej Illinej znać dal o tym statucie, któryśmy teraz na przeszlym onego naszego państwa sejmie udzialali, okolo niewydawania za męze dziewek, które ojców nie maja, bez konsensu przyjaciól bliższych..., ibidem, nr 117, s. 227; nr 181 z 21 V 1555 r., s. 308; nr 182 z 5 VI 1555 r., s. 310.
} 
jako dziedziczka wielkiego majątku stanowiła przedmiot zainteresowania licznych konkurentów. Monarcha, z uwagi na jej ogromny majątek, przeciwny był, aby wychodziła ona za koroniarza czy kogokolwiek $\mathrm{z}$ ubiegających się o jej rękę ${ }^{101}$. Mimo zaangażowania się króla w plan małżeństwa wojewody brzeskiego Łukasza Górki z Elżbietą ${ }^{102}$, jej matka, księżna Beata, nie podporządkowała się rozkazowi królewskiemu.

3.3.6. Dysponentem urzędów, królewszczyzn w państwie byl monarcha. Ważne w staraniach o różne dobra było dotarcie do panującego i uzyskanie łaski królewskiej. Radziwiłłowie, mający bezpośredni dostęp do króla, byli pośrednikami $w$ tych zabiegach o laskę. W czterdziestu czterech listach znajdujemy odpowiedzi na kierowane doń, za pośrednictwem Radziwiłłów, prośby osób trzecich ${ }^{103}$. Na pierwszy plan, $\mathrm{z}$ uwagi na liczebność, wysuwaja się protekcje o nadanie różnego rodzaju godności; jest ich trzydzieści osiem.

${ }_{101}$ Przetoż gdzieby tak bylo, iżby ja Kościelecki już pojać mial tu by więc potrzeba innych obyczajów poszukać, jakoby temu zabieżé, żeby jako panna z Litwy nie byla wyniesiona..., ibidem, nr 87 z 26 V 1550 r. do Mikolaja Rudego, s. 175; nr 149 z 3 VII 1553 r. do Mikolaja Czarnego, s. 275-276; nr 154 z 15 IX 1553 r., s. 282-283; nr 155 z 29 IX 1553 r. do Mikolaja Rudego, s. 285; nr 175 z 21 IX 1554 r. do Mikołaja Czarnego, s. 302; nr 185 z 26 X 1556 r., s. 315 ; nr 187 z 20 XI 1556 r., s. 322; nr 188 z 24 XI 1556 r., s. 324.

102 Ibidem, nr 181 z 21 V 1555 r. do Mikołaja Czarnego, s. 308; nr 182 z 5 VI 1555 r., s. 310; nr 189 z 12 XII 1556 r., s. 326; nr 192 z 28 XII 1556 r., s. 331 . Król pisal: Co za upór kssiężna Illina przeciwko naszemu rozkazaniu okolo malżenstwa dziewki swej wiedzie, et quam insolenter et procaciter z tego sie zdziera z przepisu tego listu Barzego starosty lwowskiego [...]. A iż to już agitur de dignitate nostra, bo sie już tak w tym oslawiwszy, a temu nie uczynić dosyć esset cum magno nostro dedecore, [...] żqdamy TM abyś nam TM zdanie swe wypisal..., nr 201 z 7 III 1559 r., s. 341.

${ }^{103}$ Ibidem, nr 7 z 1 I 1548 r. do Mikołaja Radziwiłła, s. 46, 47, 48; nr 11 z 2 VI 1548 r., s. 53; nr 12 do Barbary Radziwilłównej z 2 VI 1548 r., s. 55; nr 14 z 25 VI 1548 r. do Mikołaja Rudego, s. 59; nr 15 z 25 VII 1548 r., s. 61; nr 18 z 19 VIII 1548 r., s. 70; nr 19 z 25 VIII 1548 r., s. 72 ; nr 24 z 24 X 1548 r., s. 77; nr 25 z 30 X 1548 r., s. 79 ; nr 31 z 23 XI 1548 r., s. 92; nr 35 z 1 XII 1548 r., s. 95; nr 38 z 20 XII 1548 r., s. 100, 101; nr 42 z 25 I 1549 r., s. 107; nr 43 z 11 II 1549 r., s. 108; nr 49 z 21 III 1549 r., s. 116; nr 51 z 16 V 1549 r., s. 119 ; nr 56 z 31 VII 1549 r., s. 123 ; nr 61 z 25 VIII 1549 r. do Mikolaja Czarnego, s. 129; nr 62 z 11 VIll 1549 r. do Mikołaja Rudego, s. 130; nr 65 z 24 X 1549 r., s. 137; nr 66 z 13 XII 1549 r., s. 140; nr 70 z 31 XII 1550 r., s. 146; nr 81 z 21 IV 1550 r., s. 167 ; nr 84 z 28 IV 1550 r., s. $170-171$; nr 87 z 26 V 1550 r., s. 175 ; nr 91 z 2 VII 1550 r., s. $181-182$; nr 102 z 22 IV 1551 r., s. 203 ; nr 103 z 6 V 1551 r., s. 204; nr 106 z 20 V 1551 r., s. 207 ; nr 110 z 4 VI 1551 r., s. $212-213$; nr 140 z 25 III 1553 r., s. 263 ; nr 150 z 12 VII 1553 r. do Mikolaja Czarnego, s. 277; nr 169 z 16 III 1554 r. do Mikołaja Rudego, s. 297; nr 181 z 21 V 1555 r. do Mikołaja Czarnego, s. 308; nr 183 z 30 VI 1555 r., s. 312 ; nr 186 z 30 X 1556 r., s. 318 ; nr 187 z 20 XI 1556 r., s. 319 , 322; nr 209 z 29 XII 1561 r., s. 353; nr 246 z 7 XII 1562 r., s. 412 ; nr 313 z 11 VII 1567 r. do Mikołaja Rudego, s. 532; nr 320 z 13 IV 1568 r., s. 540 ; nr 325 z 22 VIII 1568 r., s. 547 ; nr 326 z I X 1568 r., s. 549 ; nr 352 z 27 III 1571 r., s. 593; nr 355 z 13 VIII 1571 r. do Mikołaja Krzysztofa Sierotki, s. 597. 
W dziesięciu przypadkach prośba dotyczyła nadania dóbr. W dwóch wypadkach nie podporządkowano się decyzji królewskiej wydanej wskutek protekcji; oba miały miejsce w $1571 \mathrm{r}$. Mianowicie, za wstawiennictwem Mikołaja Rudego u króla, ten nadał 150 włók na Żmudzi biskupowi kijowskiemu Mikołajowi Pacowi. Niektórzy z ciwunów okazali się uporni przeciw $[\mathrm{k}]$ o wolej $i$ rozkazaniu naszemu ${ }^{104}$. Król polecił wysłać listy. Jeden do starosty żmudzkiego Jana Hieronimowicza Chodkiewicza, aby ten przekazał wspomniane włóki królewskiemu dworzaninowi Sebastianowi. Drugi do dzierżawcy starostwa upickiego kniazia Piotra Kroszyńskiego, który mial wyjaśnić przyczyny niewydania włók. Te dwa listy wysyłał na ręce kanclerza Mikołaja Rudego celem przekazania ich biskupowi kijowskiemu.

Drugi przypadek również wydarzył się na Żmudzi. Synowie zmarłego kasztelana żmudzkiego Malchera Stanisławowicza Szemeta nie ustąpili z bardzo zasobnego folwarku Pojurze, należącego do uposażenia parafii w Krożach, do której prawo prezenty posiadał monarcha. Plebanię miał objąć dworzanin królewski Jakub Dalechowski, któremu w tym celu wydane zostały $\mathrm{z}$ kancelarii listy $\mathrm{z}$ podpisem królewskim. Pomimo to namiestnik kroski [...] na listy nasze nic nie dbat i owszem jeszcze byl przeciwko nim, dopomagajac we wszytkim tamtej stronie, wzbraniajac posesyji plebanowi naszemu. A miasto pomocy na przekazie [na przeszkodzie] byl... ${ }^{105}$. Wymieniony namiestnik był urzędnikiem Bobrownickiego dworzanina Mikołaja Krzysztofa Sierotki. Taka postawa sługi Radziwilla uderzała w powage władcy. Gdyz za takim poczqtkiem chcialby sie niejeden kusić, $i$ o co więtszego u nas $b r a c^{106}$. Nie chcąc dopuścić do pośmiewiska urzędu monarszego, król wysłał listy do wojewody wileńskiego Mikołaja Rudego, który mial je przekazać kasztelanowi trockiemu Ostafiemu Bohdanowicz Wollowiczowi, staroście żmudzkiemu Janowi Hieronimowiczowi Chodkiewiczowi i Mikołajowi Krzysztofowi Sierotce $\mathrm{z}$ prośbą o radę odnośnie do pozwania osoby, która przeciwstawila się woli monarchy. Nie wiemy, jak sprawa ostatecznie została rozstrzygnięta.

Do króla zwracano się nie tylko o nadanie urzędów czy dóbr ziemskich. Proszono go o wstawiennictwo w uzyskaniu u wierzyciela zwłoki w spłacie dlugu $^{107}$; o odroczenie terminu sądowego rozprawy przed królewskim sądem komisarskim w sprawie między dzierżawcą a poddanymi dóbr królewskich ${ }^{108}$; o wyrażenie zgody na to, aby namiestnik wileński mógł zamieszkać na

\footnotetext{
${ }_{104}$ Ibidem, nr 352 z 27 III 1571 r. do Mikołaja Czarnego, s. 593.

${ }^{105}$ Ibidem, nr 355 z 13 VIII 1571 r. do Mikolaja Krzysztofa Sierotki, s. 597.

${ }^{106}$ Ibidem, s. 598.

${ }^{107}$ Ibidem, nr 7 z 1 V 1548 r. do Mikołaja Rudego, s. 46.

${ }^{108}$ Ibidem, nr 102 z 22 IV 1551 r. do Mikołaja Rudego, s. 203-204.
} 
zamku wileńskim i tam sprawować sądy ${ }^{109}$; o zgodę na wypalanie popiołu w lasach na Żmudzi ${ }^{110}$.

W jednym wypadku zgoda na zgłoszoną protekcje była warunkowa: dotyczyła prośby Mikołaja Rudego o ius patronatus na kanonia u świętego Michala w Plocku dla doktora opiekującego się jego chorą matką. Zainteresowany miał je uzyskać, jeśli pomoże matce protegującego ${ }^{111}$.

3.3.7. Laska królewska przybierala różne postacie. W związku z nałożeniem podatku serebczyzny król informował adresata o zamiarze zwolnienia go $\mathrm{z}$ zapłacenia tego podatku, przenosząc ten obowiązek na dobra wielkoksiążęce. $\mathrm{Z}$ uwagi na to, że Mikołaj Rudy już podatek do skarbu uiścil, polecil wysłać kwit na 400 kop, które miałyby pokryć koszty wyprawy adresata na koronację Barbary ${ }^{112}$. Król wyrażał współczucie $\mathrm{z}$ powodu choroby osób bliskich adresatowi, oferując się z przysłaniem lekarza, który dał się poznać jako dobry doktor, gdy leczył siostrę króla Katarzynę Jagiellonkę ${ }^{113}$. Na prośbę Mikołaja Czarnego posłal mu list celem pobrania beczki wina w Wilnie od osoby, która nad winami należącymi do wielkiego księcia sprawowała pieczę $e^{114}$.

Wyrazil Radziwillowi zgodę na polowania w puszczy rudnickiej, z tym zastrzeżeniem, aby $z$ tego zezwolenia zbyt często nie korzystal ${ }^{115}$; innym razem pozwolił na upolowanie czterech jeleni $w$ Jedlnej ${ }^{116}$ czy pięciu losi, a nawet niedźwiedzia w puszczy rudnickiej ${ }^{17}$.

3.4. W pierwszych latach panowania Zygmunta II Augusta dużo miejsca w listach zajmowały sprawy związane $\mathrm{z}$ jego małżeństwem $\mathrm{z}$ Barbarą Gasztoldową. Na 113 listów z okresu listopad 1547 r. do czerwca 1551 r. wątek Barbary występuje w $77^{118}$ (co stanowi $68,1 \%$ ).

${ }^{109}$ Ibidem, nr 326 z 1 X 1568 r. do Mikołaja Rudego, s. 549.

${ }^{110} \mathrm{Ibidem}$, nr 18 z 19 VIII 1548 r. do Mikołaja Rudego, s. 70. Zwracano się za pośrednictwem Radziwillów o uzyskanie zgody na zbywanie towarów leśnych pochodzących $z$ lasów osoby proszącej. Zygmunt August wyraził zgodę pod warunkiem, iz kupcy nie będą uczestniczyli w pozyskiwaniu tych produktów, ibidem, nr 81 z 21 IV 1550 r. do Mikołaja Rudego, s. 167.

11 Ibidem, nr 70 z 31 I 1550 r. do Mikołaja Rudego, s. 146. Zdrowie chorej uległo poprawie i doktor uzyskał prawo patronatu, o czym został poinformowany Zygmunt August, ibidem, nr 75 z 17 III 1550 r., s. 159.

112 Ibidem, nr 94 z 19 IX 1550 r. do Mikołaja Rudego, s. 191-192.

113 Ibidem, nr 43 z 11 Il 1549 r. do Mikolaja Rudego, s. 108; nr 70 z 31 I 1550 r. do Mikolaja Rudego, s. 145; nr 215 z 26 I 1562 r. do Mikolaja Rudego, s. 363; nr 216 z 30 I 1562 r. do Mikołaja Rudego, s. 364.

114 Ibidem, $\mathrm{nr} 42$ z 26 I 1549 r., s. 107.

11s Ibidem, nr 7 z 1 V 1548 r. do Mikotaja Rudego, s. 47.

116 Ibidem, nr 272 z 15 III 1564 r. do Mikolaja Czarnego, s. 456.

117 Ibidem, nr 335 z 9 XII 1568 r. do Mikolaja Rudego, s. 566.

${ }^{118}$ Sq to listy $\mathrm{nr}: 1-8,10-16,18-33,35,37-40,50-54,57-58,60,65,68,70 ; 72-73,75 ; 77-78$, 82,$84 ; 86,88-90,92-97,99-101,103-109,111-113$. Poza tym w listach z 25 III i 25 IV 1553 r. do Mikołaja Rudego poruszono sprawę rzekomej pożyczki pod zastaw zaciągniętej przez Barbarę, a spłaconej przez jej brata Mikołaja Rudego, zob. nr 140, s. 263; nr 143, s. 268. 
Król poświęcał dużo uwagi zdrowiu swej oblubienicy i opiece nad nią. Polecal Mikołajowi Rudemu sprawującemu opiekę nad Barbarą dopilnować, aby Jej $M$ tak dlugo $w$ laźni się nie myla. Gdyz to Jej $M$ [...] zdrowiu $s z k o d z i^{119}$. Król widział wszędzie czające się zło, dlatego starał się o izolowanie Barbary od otoczenia. Obawiając się, iż zle wieści z zewnątrz mogą wpływać negatywnie na jej zdrowie psychiczne, zabraniał jej otoczeniu dostarczania ich Barbarze ${ }^{120}$. Wiadomości takie dochodzily jednak do Barbary, co dokumentuje list do niej z 24 listopada 1548 r., w którym wyrazil zdziwienie, że dawała ona wiarę czyimś opowieściom, a nie jego slowom ${ }^{121}$.

Podejrzewal swoją matkę, królową Bonę, o złe zamiary względem swej żony. W liście do Mikołaja Rudego z 3 stycznia 1548 r. zapytywał, jak doszło do zawalenia się sklepienia (podłogi) komnaty, w której była Barbara. Podejrzewal, iż była to próba zamachu na jej życie: ...bo dziś wiele zlych ludzi, co się o zle radzi przyczyniaćl22. Udzielał wskazówek, do którego $\mathrm{z}$ kościołów w Wilnie ma ona uczęszczać. Wskazane było, aby nie chodziła ona na msze do kościoła ś. Stanisława, gdyż tam prowadzone były prace budowlane $i$ nie barzo jest bezpieczno tam chodzić, abowiem może sie co w tem stać, abo cegla sama spadnie, abo jq też kto zrzuci na nię ${ }^{123}$. Zezwalał jeździć Barbarze do Wierszup pod Wilnem, gdzie znajdowała się letnia rezydencja Zygmunta Augusta, lecz miało się to odbywać z zachowaniem przez Mikołaja Rudego największych środków ostrożności. W związku $\mathrm{z}$ mającym nastąpić wkrótce przyjazdem małżonki do Korony, Zygmunt August na jej prośbę daje jej rady, jak ma być ubrana na ich spotkanie. Miała być $w$ szacie czarnej $z$ sukna wloskiego $i$ także też $w$ plachtach nie $w$ miqższych [grubych - T. S.], jakoby $w$ rantuchach [duża chusta noszona przez zamężne kobiety na plecach lub służąca do przywiązywania czepca nad czołem] ${ }^{124}$. Przestrzegal Mikołaja Rudego, aby orszak z Barbara nie wstępowal, po drodze do Radomia, do klasztoru benedyktynów i kościoła ś. Krzyża na Łysej Górze. Tam - według ostrzeżenia otrzymanego przez króla - grozilo Barbarze niebezpieczeństwo ${ }^{125}$.

119 Ibidem, nr 33 z 24 XI 1548 r., s. 94.

${ }^{120} \mathrm{~W}$ liście do Mikołaja Rudego z 25 VII $1548 \mathrm{r}$. dziękował mu, że on tak jak kasztelan lubelski Stanisław Maciejowski się z pilnościq zawżdy przyczyniacie, jakoby przed wiadomość Jej KM żadne takowe rzeczy nie przychadzaly, które by Jej KM jako niedobra mysl czynic i przynosić mogly..., ibidem, nr 15, s. 60; nr 28 z 15 XI 1548 r., s. 87; nr 30 z 19 XI 1548 r., s. $89 ; \mathrm{nr} 78$ z 28 III 1550 r., s. 164-165.

121 Ibidem, nr 32, s. 93.

${ }^{122}$ Ibidem, nr 3 z 3 I 1548 r. do Mikołaja Rudego, s. 42; zob. komentarz M. B alińs ki e go w: Pisma historyczne..., t. I, Warszawa 1843, s. 79-81.

${ }^{123}$ Ibidem, nr 13 z 16 VI 1548 r. do Mikołaja Rudego, s. 57.

124 Ibidem, nr 19 z 25 VIII 1548 r. do Mikołaja Rudego, s. 72.

125 Ibidem, nr 22 z 16 X 1548 r. do Mikołaja Rudego, s. 75. 
Gdy przyjadą do Piotrkowa, ma dopilnować, aby na pokoju królowej Jej $M$ bialoglowy pić nie dawaty, a zwlaszcza $z$ kubków, abowiem [...] $z$ szklennic lacniej by sie wszystko obaczyć mogło. Większe zaufanie król miał do męskiej shużby ${ }^{126}$. Obawa przed otruciem Barbary nie opuszczała Zygmunta Augusta. W liście wysłanym kilka dni później $z$ naciskiem podkreślał, iż podawanie napojów w dzień nie stanowi tak dużego problemu, jak w nocy: ...w nocy daleko trudniej, bo konew abo kubek z piciem bedzie na stole postawion, okolo którego bialoglowy chodzić i trzasść sie muszq [...] nikt nie obaczy, [co] $w$ ono picie wrzucono abo nasypano... ${ }^{127}$. Żąał od Mikołaja Rudego, aby naczynia, $z$ których Barbara pije, były $w$ nocy przechowywane w zamkniętej na klucz szafce, zaś picie podawała wówczas ta bialoglowa, której by sie wierzyć godzilo.

Tragedią dla Zygmunta Augusta była choroba małżonki. Gdy Barbara zachorowała, król zwrócil się do Mikołaja Rudego o niewiastę biegłą w sztuce czarów, która pomogłaby jego żonie $w$ pomnożeniu zdrowia. Sam również podejmuje działania uwieńczone powodzeniem za pilnym naszym staraniem naleźliśmy byli niejaka niewiaste, która et in hac magica arte dobrze umiejetna jest,$i$ tez jenak to, co do tego potrzebnego być rozumiala, z pilności czynila ${ }^{128}$. $\mathrm{Z}$ usług kobiety biegłej w sztuce zamawiania król bedzie jeszcze korzystać, gdyż problemy zdrowotne Barbary nie skończyły się ${ }^{129}$ Zygmunt II August był nieufny w stosunku do wszystkich. Rozkazał Mikołajowi Czarnemu przybyć do Piotrkowa, gdzie odbywal się sejm, celem towarzyszenia Barbarze, Bo tez $t u$ nie mamy kumubyśmy tak bezpiecznie ufać mogli ${ }^{130}$. Był bardzo zaniepokojony wiadomością, iż w Gomolinie pod Piotrkowem zamieszkała jego matka, królowa Bona, która przywiozla [...] bela ze sobq wielkiego ożoga to jest czarownice, którq od dawnego czasu Warszewie miala [...]. Myśmy te czarownice tu dostali $i$ jest juz $u$ nas $w$ klatce, śpiewa dosyć niemalo rzeczy ${ }^{131}$. Był przekonany, że celem czarownicy było doprowadzenie Barbary do zguby.

Planując koronację Barbary, Zygmunt August chcial utrzymać wszelkie przygotowania w zupełnej tajemnicy, w tym także przyjazd na tę uroczystość Mikołaja Rudego ${ }^{132}$. Uważał, że dla Bony najlepszym i to pożądanym rozwiązaniem byłaby śmierć synowej. Był ogromnie zdziwiony, że mimo utrzymywania przygotowań $w$ gł̨̨bokiej tajemnicy, wieść o zamierzonej koronacji wyszła na jaw ${ }^{133}$.

${ }^{126}$ Ibidem, nr 23 z 20 X 1548 r. do Mikołaja Rudego, s. 76.

${ }^{127}$ Ibidem, nr 25 z $30 \times 1548$ r. do Mikolaja Rudego, s. 79 , zob. też s. 78 .

${ }^{128}$ Ibidem, nr 77 z 24 III 1550 r., s. 160.

${ }^{129}$ Ibidem, nr 96 z 5 III 1551 r. do Mikołaja Rudego, s. 196; nr 99 z 24 III 1551 r., s. 198.

${ }^{130}$ Ibidem, nr 86 z 3 V 1550 r. do Mikołaja Rudego, s. 174.

131 Ibidem, nr 89 z 20 VI 1550 r. do Mikołaja Rudego, s. 177.

${ }_{132}$ Ibidem, nr 90 z VI 1550 r., s. 179; nr 93 z 20 VIII 1550 r., s. 188; nr 94 z 19 IX 1550 r., s. 189-191; nr 95 z 15 X 1550 r., s. 193-194.

133 Ibidem, nr 95 z 15 X 1550 r., s. 193. 
Barbara miała być pochowana w Wilnie. Przed wyjazdem z Krakowa Zygmunt August pytal się astrologa, profesora Akademii Krakowskiej, co może go spotkać w drodze do Wilna. Astrolog z gwiazd wyczytal, że na kilku miejscach $w$ drodze trzeba obawiać sie [...] ognia ${ }^{134}$. Król lączył tę wróżbę z zamiarem królowej Bony, która przez działania baby-czarownicy chciała zaszkodzić królowi.

3.5. Niefortunnym dla interesów monarchy był jego konflikt $\mathrm{z}$ matką, królową Boną, który znajduje odzwierciedlenie w listach ${ }^{135}$. Od początku panowania posądzał matkę o organizowanie opozycji ${ }^{136}$; podejrzewał ją o złe zamiary względem jego żony Barbary Gasztołdowej; uważał, że zdolna jest wynająć kogoś za pieniądze, kto pokrzyżowałby plany koronacji Barbary ${ }^{137}$.

O zabiegach królowej Bony, zmierzających do pogodzenia się z synem i uznania przez nią Barbary za synową i córkę, dowiadujemy się $\mathrm{z}$ listu króla do Mikolaja Rudego z 1 kwietnia 1551 r. Wówczas to wysłannik Bony, Franciszek Lismanin, był u Barbary na uroczystym, publicznym posłuchaniu. $Z$ relacji Zygmunta II Augusta wynika, iż matka już wcześniej podejmowała próby pojednania się z nim; ponieważ jednak czuł się on wielce obrażony, starania te odtrącal. Mimo to Bona nie rezygnowała ${ }^{138}$. Zygmunt II August nie przełamał się w swoich uprzedzeniach, komentując z satysfakcją uznanie przez Bonę małżeństwa z Barbarą, acz to już tak smaczne poselstwo królowa Jej $M$ do malżonki naszej wskazala, wszakoż wolemy, iż sie przez listy raczej nawiedzać bedq, niżliby sie mialy czesto po spolu widaci ${ }^{139}$.

Po śmierci Barbary Bona nadal usilnie wyciągała rękę do porozumienia się z synem, lecz on nie potrafił zmienić swej dotychczasowej postawy. Brakowało mu elastyczności koniecznej w stosunkach międzyludzkich. Był zapiekły w nienawiści. W trakcie kolejnej próby zbliżenia się Bony do syna, w styczniu 1552 r., wśród wielu poruszanych spraw rozmowa zeszła na plany małżeńskie Zygmunta. Ten, nie podejmując wątku, obwinił Bonę

i34 Ibidem, nr 108 z 1 VI 1551 r. do Mikolaja Czarnego, s. 210-211; nr 109 z 2 VI 1551 r. do Mikołaja Rudego, s. 212.

${ }^{135}$ Zob. listy $\mathrm{nr}: 4,15,86,89,90,100,108,109,116,121,122,129,140,141,152,153,162$, $175,182,183,185,195$.

136 Ibidem, nr 15 z 25 VII 1548 r. do Mikołaja Rudego, s. 64.

${ }^{137}$ Zwwlaszcza o tym sie jasnie slyszeć dawa, iż nic by raczej widzieć [Bona - T. S.] nie chciala tylko śmierć, gdzieby koronacyja malżonki naszej dojć miala. Przeto bacząc matkę nasze tej myśli przeciw nam i przeciw malżonce naszej być, nic więcej nie jest potrzeba, jeno abyśmy to jakokolwiek co naskryciej postanowić mogli; bo pieniqdze, w których jeno samych matka nasza confidit wiele in hac hominum et temporum iniquitate mogq..., ihidem, nr $90 \mathrm{z}$ VI $1550 \mathrm{r}$. do Mikołaja Rudego, s. 178.

${ }_{138}$ Ibidem, nr 100 z 1 IV 1551 r. do Mikolaja Rudego, s. 200-201.

${ }^{139}$ Ibidem, s. 202 
o przedwczesną śmierć swoich dotychczasowych żon ${ }^{140}$. Obsesyjne podejrzenie, że matka jest trucicielka, powoduje u niego lęk o własne życie, co demonstracyjnie okazuje Bonie ${ }^{141}$. Nie potrafil dostrzec dobrej woli matki, a w listach utwierdzał się w swym negatywnym do niej nastawieniu ${ }^{142}$. W liście z 15 kwietnia 1552 r., pisanym do Mikołaja Rudego, pojawia się informacja o zamiarze matki wyjazdu do Włoch celem poratowania zdrowia ${ }^{143}$. Chcąc nakłonić ja do zrezygnowania $\mathrm{z}$ tego zamiaru, Zygmunt August przekazał sprawę pod obrady Senatu, który wysłal do niej posłów mających wywrzeć na nią stosowną presję ${ }^{144}$. Bona zdawala sobie sprawę, że trudności stwarzane wokół jej wyjazdu spowodowane były postawą jej syna, czemu dała wyraz $w$ rozmowie $\mathrm{z} \mathrm{nim}{ }^{145}$.

W styczniu 1553 r. doszło do kolejnego spotkania Bony z synem. Zygmunt August podkreślał, iż matka przyjęla go życzliwie, pogodnie. Wypowiadała się modestissimis verbis [...] sine cuiusvis furias significatione. Wskazywała na szkody, jakie wyrządzil im konflikt; zwróciła uwagę na nadmierne rozdawnictwo stosowane przez króla. Syn nie zamierzał jej ustępować ${ }^{146}$ - zachowywał się jak duże, rozkapryszone dziecko. Nie doszło więc do żadnego porozumienia. Król i tym razem okazał się niezbyt dobrym dyplomatą.

$\mathrm{Z}$ wyjazdem Bony łączył obawę, iż matka zabierze uzbierany przez siebie majątek, bowiem informowano Zygmunta II Augusta, iż Bona wywozi

${ }^{140}$ Ibidem, nr 116 z 20 I 1552 r. do Mikołaja Czamego, s. 224.

141 Ibidem, s. 227.

${ }^{142}$ Pisal do Mikołaja Czarnego: Owa panie wojewodo nie myśli Jej $M$ [Bona - T. S.] o tym, aby nam kiedy co dobrego czyniela, $i$ owszem, $i$ po śmierci rada by to widziala, abyśmy za jej przyczynq $w$ trudnościach beli..., ibidem, nr 116, s. 225, zob. s. 227.

143 Ibidem, nr 121, s. 233-234.

${ }^{144} \mathrm{Ci}$ nomine conventus $J e j \mathrm{M}$ o to prosić bedq multas rationes adducendo żeby Jej $M$ to przedsiewzięcie swe okolo jachania do Wloch zaniechala. Gdzie wiecby na perswazyje tych postów Jej $M$ się nie zdalo by przestać, tedy na koniec poszeptać maja Jej $M$, iż tego jachania rady koronne Jej $M$ nie pozwolq, a przeto to przedsięwziecie, które cum indignitate Regni et cum insecuritate est, lepiej iżby Jej $M$ tu doma zaniechala, niżliby to już alia via Jej $M$ mialo być bronione [...]. A to wszytko poselstwo ma być sprawowane vigore conventus, aby rzecz tym ostrzej $i$ poważniej szla. A myśmy też to poselstwo umyślnie tak vigore conventus et non solum nostro nomine rozkazać kazali, iżby Jej $M$ rozumiala iz to nie tylko $z$ nas ale wszytkich koronnych rad idzie..., ibidem, $\mathrm{nr} 121$ z I5 IV $1552 \mathrm{r}$. do Mikolaja Rudego, s. 234.

${ }^{145}$ Król na prośbę Bony o wyrażenie zgody na wyjazd stwierdził: ...iż my sami na to przyzwolić nie możemy, ale na sejmie chcemy sie $w$ tym rad naszych dolożyć. Ona powiedziala, co do tego rady maja, jeno tylko WKM sam przyzwolić chciej..., ibidem, nr 116 z 20 I 1552 r. do Mikołaja Czarnego, s. 221.

${ }^{146}$ Ibidem, nr 129 z 7 I 1553 r. do Mikolaja Czarnego, s. 245-246. W rozmowie Bona argumenty Zygmunta Augusta wdzięcznie jakoby przyjmowala, tedy drugdy errata sua jakoby confiteri visa. Ale podobno eam confesionem parva vel nulla prorsus poenitentia subsequi videbatur..., ibidem, s. 246. Syn zapewne oczekiwał, iż matka całkowicie się przed nim upokorzy (?) 
ogromne kwoty do Wloch. Radził się zatem Mikołaja Czarnego, czy nie należałoby się zwrócić do króla rzymskiego, Ferdynanda Habsburga, by ten ukrócil tę praktykę. Gdyby zaś miało to spowodować, iż pieniądze dostaną się w ręce Ferdynanda i nie wrócą do Zygmunta, sprawę należało zostawić w spokoju ${ }^{147}$. Wydarzenia przybieraly niekorzystny obrót: otrzymał bowiem z Wenecji wiadomość, iż matka darowała cesarzowi Karolowi V 150 tysięcy czerwonych złotych, nadto zmawia się $\mathrm{z}$ nim, by syn nie mógł objąc po niej $w$ posiadanie Bari we Włoszech, jak też nosi się $\mathrm{z}$ zamiarem rozdysponowania nieruchomości $i$ ruchomości $w$ Królestwie i na Litwie, by nie dostaly się jej synowil ${ }^{148}$. Nie potrafiąc, czy też nie chcąc się pogodzić z Boną, wysłal posłów do króla rzymskiego z prośbą o udzielenie ojcowskiej rady $w$ sprawie konfliktu $z$ matką. Obawiając się, iż zamiary Bony, o których informowano go we wspomnianym liście, mogą się urzeczywistnić, zwrócił się do cesarza $z$ prośbą o to, aby ten nie naruszył jego praw. $\mathrm{O}$ wszystkich posunięciach informował Mikołaja Czarnego. Chcąc zapobiec wyjazdowi matki, stwierdzal: ...my nie widziemy innej drogi, jakoby sie temu inaczej zabieżeć mialo, jeno iżby Jej $M$ prawie w kleszcze bela wzięta, a iżby tylko Jej $M$ we wszytkiej poczciwości bedąc opatrzona, sobie siedziala nic ni o czym nie wiedzacc ${ }^{149}$. Król nie dopuszczal zatem innej możliwości rozwiązania konfliktu, jak tylko odsunięcie Bony na boczny tor - tak, by wyłączyć ją $\mathrm{z}$ aktywnego życia politycznego. Ostatecznie królowa uzyskała zgodę na opuszczenie królestwa ${ }^{150}$.

3.6. Problemy z zakresu polityki zagranicznej są przedmiotem poruszanym w 78 listach $^{151}$. Do większych spraw, którymi się zajmowano, należały: podporządkowanie Inflant państwu Jagiellonów; stosunki z Wielkim Księstwem Moskiewskim (m. in. zabiegi Iwana IV u papieża o koronację; kwestia rzekomej śmierci Iwana IV); rozgraniczenie z Księstwem Pruskim; wyjazd królowej Bony do Wloch; stosunki z Tatarami i Wołochami; zabiegi matrymonialne Zygmunta Augusta; starania o rękę Jagiellonek; starania o obce pożyczki. W wyliczonych powyżej zagadnieniach dominowały kwestie związane ze stosunkami z Moskwą i z tematyką inflancką.

147 Ibidem, nr 152 z 17 VII 1553 r., s. 278-279.

148 Ibidem, nr 153 z 7 IX 1553 r. do Mikołaja Czarnego, s. 280.

i49 Ibidem, s. 281. W XVI w. termin kleszcze używany był na oznaczenie: (a) narzędzia składającego się z dwóch ruchomych części, służącego do chwytania, ściskania, miażdżenia, jak cęgi, szczypce; (b) instrumentu chirurgicznego; (c) narzędzia tortur, zob. Slownik polszczyzny XVI wieku, t. X, red. M. R. Mayenowa, Wrockaw 1976, s. 355.

iso Listy króla.., nr 183 z 30 VI 1555 r. do Mikołaja Czarnego, s. 312.

Is1 $\mathrm{Sa}$ to $\mathrm{nr}: 3,57,63,70,116,120-122,129,131,133,134,138,141-143,145,146,152$, $153,162,178,181,183,184,186-189,192,195,197,198,202,203,208,209,211,215$, $217-219,233,239,240,243,249,257,262,268,272,277,279,285,286,289,292,294$, $305,307,308,314,321,324,329,330,343-345,347,350,351,353,354,358,361,364,365$. 
Poruszane były również sprawy mające charakter marginalny. Przykładem tego jest prośba M. Czarnego o zgodę na to, by palatyn Renu mógł przegonić 150 (póltorasta) wolów ${ }^{152}$, czy wstawiennictwo za księciem cieszyńskim Janem z Podjebradu, dłużnikiem królewskim, o przesunięcie terminu spłaty długu ${ }^{153}$.

4. W korespondencji przeważała tematyka litewska. Lektura listów unaocznia uczestnictwo króla we wszystkich sprawach jego państwa - tak istotnych, jak i błahych - gdzie kwestie publiczne przeplatały się z prywatnymi. W listach nie dostrzegamy gradacji ważności problemów; widać, że władca dużo uwagi poświęcał sprawom drugorzędnym. $Z$ kart listów nie wyziera ani polityk wielkiego formatu, ani reformator. Był monarchą $\mathrm{z}$ laski Bożej i nie zamierzał rezygnować z żadnej cząstki swojej władzy. W treści spraw poruszanych $w$ korespondencji trudno dopatrzyć się programu, który monarcha chciałby realizować.

Nad współpracę z ruchem reformatorskim przedkładał związek z senatem, nie udzielając poparcia reformom, które usprawnić mogłyby funkcjonowanie państwa szlacheckiego.

Król stał twardo na stanowisku utrzymania odrębności Korony i Litwy jako związku opartego na zasadzie równości obu partnerów. Obstrukcja stosowana przez Zygmunta II Augusta zaowocuje stępieniem ostrza żądań wysuwanych przez szlachtę koronną $w$ sprawie unii polsko-litewskiej.

Trudno uznać go za polityka dalekowzrocznego. Choć sprawa uregulowania następstwa tronu na wypadek jego śmierci byla podnoszona w czasie obrad sejmowych, to przy braku dostatecznego poparcia Zygmunta II Augusta nie mogła być rozstrzygnięta. W rezultacie nie ustalono regul funkcjonowania władzy w okresie bezkrólewia ani zasad elekcji. Zaważy to w przyszłości negatywnie na losach Rzeczypospolitej.

Przedkładaniem spraw prywatnych, osobistych, nad rację stanu było małżeństwo z Barbarą Gasztoldową. Doprowadziło to do powstania opozycji antykrólewskiej, zmuszając monarchę do nadmiernego rozdawnictwa dóbr i urzędów w celu jej neutralizacji.

Zygmunt II August nie był politykiem łączącym umiejętność rokowań, dyplomacji z koniecznością pójścia niekiedy na kompromis. Widzimy to na przykładzie jego stosunku do matki - królowej Bony. Król, ogarnięty irracjonalną niechęcią do niej, odrzucał wszelkie podejmowane przez nią próby porozumienia - tak za życia Barbary, jak i po jej śmierci. To zaowocuje wyjazdem Bony, połączonym $z$ wywozem ogromnych sum, które

\footnotetext{
${ }_{152}$ Ibidem, nr 57 z 3 VIII 1549 r. do Mikolaja Czarnego, s. 124.

153 Ibidem, nr 188 z 24 XI 1556 r. do Mikołaja Czarnego, s. 323.
} 
mogłyby zostać wykorzystane $w$ interesie monarchii. Całość jego poczynań sprawia wrażenie, że nie był przygotowany do sprawowania rządów tak wielkim państwem.

Rodzi się pytanie. Jak Zygmunt II August przedstawia się na tle wladców szesnastowiecznej Europy: czy zaliczymy go do elity ówczesnych monarchów, czy zdecydowanie należal do średniej europejskiej klasy panującej? Przeprowadzenie wyczerpujących badań porównawczych pozwoliłoby uzyskać odpowiedź na postawione pytanie. 